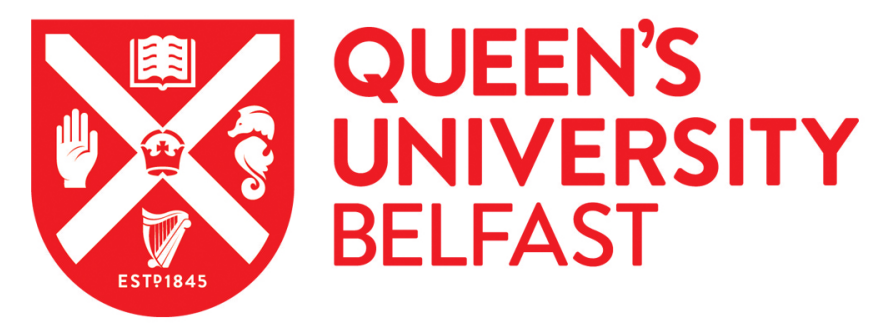

\title{
Evaluation of full scale shear performance of tension anchor foundations: Load displacement curves and failure criteria
}

Bergamo, P., Donohue, S., Callan, D., Holland, A., McCarey, J., Brown, W., McSherry, M., Ward, C., Amato, G., \& Sivakumar, V. (2017). Evaluation of full scale shear performance of tension anchor foundations: Load displacement curves and failure criteria. Ocean Engineering, 131, 80-94.

https://doi.org/10.1016/j.oceaneng.2016.12.033

Published in:

Ocean Engineering

Document Version:

Peer reviewed version

Queen's University Belfast - Research Portal:

Link to publication record in Queen's University Belfast Research Portal

Publisher rights

(c) 2017 Elsevier Ltd. This manuscript version is made available under the CC-BY-NC-ND 4.0 license http://creativecommons.org/licenses/by$\mathrm{nc}-\mathrm{nd} / 4.0 /$ which permits distribution and reproduction for non-commercial purposes, provided the author and source are cited

\section{General rights}

Copyright for the publications made accessible via the Queen's University Belfast Research Portal is retained by the author(s) and / or other copyright owners and it is a condition of accessing these publications that users recognise and abide by the legal requirements associated with these rights.

Take down policy

The Research Portal is Queen's institutional repository that provides access to Queen's research output. Every effort has been made to ensure that content in the Research Portal does not infringe any person's rights, or applicable UK laws. If you discover content in the Research Portal that you believe breaches copyright or violates any law, please contact openaccess@qub.ac.uk. 


\section{EVALUATION OF FULL SCALE SHEAR PERFORMANCE OF TENSION ANCHOR FOUNDATIONS: LOAD DISPLACEMENT CURVES AND FAILURE CRITERIA}

Paolo Bergamo ${ }^{1,2}$, Shane Donohue ${ }^{1}$, Damian Callan ${ }^{3}$, Adam Holland ${ }^{3,4}$, John McCarey $^{3}$, William Brown ${ }^{3,5}$, Michael McSherry ${ }^{3}$, Cillian Ward ${ }^{3}$, Giuseppina Amato ${ }^{1}$, V. Sivakumar ${ }^{1}$

${ }^{1}$ School of Natural and Built Environment, Queen's University Belfast, Stranmillis Road, BT95AG, Belfast, UK.

${ }^{2}$ present address: Schweizer. Erdbebendienst, ETH Zurich, Sonneggstrasse 5, 8092 Zurich, Switzerland.

${ }^{3}$ McLaughlin and Harvey Ltd., 15 Trench Rd, Newtownabbey BT36 4TY, Northern Ireland ${ }^{4}$ present address: Fast Engineering Ltd, 5 Windmill Court, Antrim BT41 2TX, Northern Ireland. ${ }^{5}$ present address: Gavin \& Doherty Geosolutions Engineering UK Ltd, 7 Donegall Square West, Belfast BT1 6JH.

Corresponding author: Shane Donohue, email: s.donohue@qub.ac.uk 


\begin{abstract}
One of the biggest challenges faced by the offshore wave and tidal energy industry is the high cost of constructing and installing offshore foundations. Foundations based on post tensioned pile anchors can be effectively proposed to tackle this issue. A series of full-scale direct shear tests were performed on-shore to evaluate the shear resistance of post-tensioned pile anchor foundations designed for securing tidal turbine devices to a rock seabed. We focused, in particular, on the primary shear resistance mechanism of post-tensioned anchors, by applying a vertical force which mobilizes, a frictional force able to resist horizontal thrusts. Different load paths, involving monotonic or cyclic loading, were applied; several configurations for the footing of the foundation were tested. The footing stress-displacement behavior and the stress conditions at sliding failure from a number of different testing configurations were compared and analyzed. A marked consistency with the shear performance of natural rock joints was identified. This allows the behavior of tension pile foundations subjected to substantial horizontal loads to be modelled using relationships developed for rock joints, widely available in the literature. Additionally, the results obtained from different tests were also collated considering the various configurations adopted for the foundation-rock system and the applied load paths, to identify the factors that affect the shear resistance of the foundation.
\end{abstract}

KEYWORDS: Post-tensioned anchor, offshore foundation, marine energy, shear performance, direct shear test, full-scale testing 


\section{SYMBOLS}

A: area

$\alpha$ : asperity angle

$c_{0}$ : cohesion intercept

$d_{h}$ : shear, horizontal displacement

$d_{v}:$ normal, vertical displacement

$d_{v j}$ : vertical displacement related to the closure of the rock joint and failure of asperities (net deformation or closure)

$d_{v r}$ : portion of vertical displacement due to solid rock compression

$d_{v t}:$ total vertical displacement

$f_{h}$ : shear, horizontal force

$f_{h a}$ : horizontal asymptotic load of the $f_{h}-d_{h}$ curve

$f_{v}$ : normal, vertical force

$\varphi_{b}:$ basic friction angle

$K_{j}$ : stiffness number

$K_{n j i}:$ initial normal stiffness for rock joint closure or failure

$K_{n r i}$ : initial normal stiffness of solid rock compression

$k_{s i}$ : initial shear stiffness referred to the $f_{h}-d_{h}$ curve

$K_{\mathrm{si}}$ : initial shear stiffness referred to the $\tau$ - $d_{h}$ curve

$n_{j}$ : stiffness exponent

$R_{f}$ failure ratio

$\sigma_{n}:$ normal, vertical stress

$\sigma_{n a}$ : horizontal asymptote of the $\sigma_{n}-d_{v r}$ curve.

$\tau$ : shear stress

$\tau_{a}$ : horizontal asymptotic of the $\tau-d_{h}$ curve

$\tau_{\max }:$ shear stress at failure

$V_{m}$ : maximum achievable closure for a rock joint 


\section{INTRODUCTION}

Among the most promising sources of renewable energy, the harvesting of electrical power from wind turbines or wave/tidal power generators, is a key resource in the area of the British Isles, because of the vast potential of offshore energy reserves (UK Government, 2003; DETINI, 2009; Renewable UK, 2013; EMEC, 2016). In this context, a critical problem currently encountered by civil engineering is the realization of adequate foundation systems for wind/wave/stream offshore turbine devices. These foundations must be capable of connecting these structures to the seabed and of transferring the loads applied to the turbines safely to the ground (e.g. Adhikari and Bhattacharya, 2011; Bhattacharya et al., 2012; Abhinav and Saha, 2015). These demanding engineering tasks significantly affect the installation costs of such turbines and may constitute up to $35 \%$ of the installed cost (Byrne and Houlsby, 2003). This influences negatively the cost competitiveness per megawatt when compared to energy from fossil fuels (DETINI, 2009).

Over recent years, several foundation solutions for tidal power generators have been developed and implemented. The most common solutions, that have been used for a range of different environments (e.g. water depth, nature of seabed), are: gravity foundations (e.g. McLaughlin and Harvey, 2016), piled foundations (e.g. Whittaker et al., 2007; Spagnoli et al., 2013), moored foundation solutions (Jeffcoate et al., 2015; Scotrenewables, 2016;), tripods with buckets and suction buckets. The advantages and disadvantages of each of these systems have previously been established (IEA - RETD, 2012). Considering the need to meet challenging engineering requirements and to reduce construction and deployment costs, the offshore foundation industry is continuously evolving, with new or hybrid solutions being developed. Recently, the use of foundations for tidal turbines based on post-tensioned anchors has been proposed, jointly with a system for their efficient installation in offshore environments (Callan et al., 2012). This foundation type aims to provide the tidal turbine with 
sufficient bearing resistance, whilst at the same time reducing the overall size of the foundation when compared to gravity based foundations (thereby reducing concrete requirements). This system consists of small-diameter hollow bars drilled in the rocky seabed and secured to the underlying rock volume by means of grout bond. When tensioned using hydraulic jacks, they apply a vertical force on the underwater structure that replicates the self-weight of a ballasted structure to ensure its stability (Figure 1). The technology of post tensioned anchors (hereafter referred to as "tension anchors") is readily available and widely used for a range of onshore applications (e.g. as micropiles for foundations and anchorages, soil nails for reinforcing soil, slopes or tunnels; see for instance standards BS EN 14490, 2010, and BS EN 14199, 2015, within Eurocode 7, 1997). Conversely, the use of tension anchors in underwater applications is less common, because of the difficulties in tensioning the anchors in the subsea environment, where access and operating conditions might be extremely difficult; hence these topics are currently the subject of industry research and development (Callan et al., 2012; Meggitt et al. 2013; Tiwari et al. 2014). Additionally, underwater structures may be subjected to substantial horizontal loads, e.g. generated by tidal currents (de Jesus Henriques et al., 2014) or induced by wave action, that the foundations are required to resist. Studies found in the literature that discuss the performance of piles or anchors embedded in rock mainly focus on the evaluation of their shaft resistance (see for instance Gu and Haberfeld, 2004; Serrano and Olalla, 2004 and 2006) rather than on their behavior when subjected to significant shear forces.

To assess the potential of tension anchor foundations to resist significant horizontal loads, as typically found in a tidal environment, a set of full scale, direct shear tests were conducted. These tests were performed onshore, on a particular foundation primarily designed to fix tidal stream turbines to a rock seabed (Callan et al., 2012), constituted by a circular footing connected to the bedrock by means of a post-tensioned anchor. These trials 
are part of a wider experimental phase aimed at testing the performance of this foundation system prior to offshore installation in its planned working environment (i.e. a shallow sea, with a depth of few tens of meters, with substantial tidal currents). In the experiments presented in this paper, the tension anchor foundation supports a specifically designed test rig through which normal and shear loads are applied to the foundation (Figures 2, 3). This experimental apparatus was installed in a schist quarry (Ballykinler, Co. Down, Northern Ireland) in order to test the tension anchor system on a weathered, poor quality rock. Additional tests on other imported rock types were also carried out (e.g. sandstone, gritsone or granite rock, concrete). Several configurations for the footing of the foundation were adopted. Different loading scenarios were applied during the tests, including (1) monotonic loading until the peak shear strength was mobilized, and (2) bidirectional cyclic shear loading until failure. The resultant shear and normal displacements were measured at the foundation footing by means of linear variable differential transformer (LVDT) sensors.

In both the experimental and subsequent analysis phases, attention was focused on the primary shear loading resistance mechanism of post-tensioned anchors, by applying a vertical force which mobilizes a frictional force able to resist horizontal thrusts (Figure 1). Indeed, the anchor itself also opposes horizontal movements; however, this mechanism comes into play at large displacements, when the rock-foundation footing coupling has already failed, and the anchor provides the residual shear resistance. The evaluation of the resistance provided by the anchor is, however, not within the scope of this work. Therefore, testing and analyses was focused on relatively small displacements, and failure was considered to occur when the foundation footing-rock adhesion fails, so that the footing "slides" on the rock surface, save for the constraint later posed by the anchor.

The experimental apparatus and details of the tests are described in "Experimental method" (Subsections 2.1, 2.2). The acquired datasets were studied and interpreted with 
reference to the scientific literature concerning the shear behavior of natural rock joints (Subsection 2.3). In this area of study, a wide range of works have focused:

i) on the analysis of load-displacement relations for rock discontinuities prior to failure (e.g. Kuhlawy, 1975; Hungr and Coates, 1978; Kuhlawy, 1978; Bandis 1980; Bandis et al., 1983);

ii) on the definition of criteria representing the state of stress at failure for rock discontinuities (e.g. Patton, 1966; Jaeger, 1971; Barton, 1973; Hoek and Brown, 1980).

For both aspects, the behavior displayed by the foundation footing-rock system in the tests carried out showed an appreciable degree of consistency with the response described and modeled for natural rock joints in literature. This allows the relationships developed for rock joints, widely considered in the literature, to be used for modelling the performance of tension anchor foundations subjected to substantial horizontal loads. The results obtained from different tests were also analyzed considering the various configurations adopted for the foundation-rock system and the applied load paths, to identify the factors that affect the shear resistance of the foundation ("Results and Discussion", Section 3).

\section{EXPERIMENTAL METHOD}

\subsection{Experimental apparatus}

The foundation tested in this study is a post-tensioned anchor foundation (Callan et al., 2012). This is constituted by a ground anchor embedded in the rock mass, tensioned to exert a downward normal force on the foundation footing, which is a circular steel frame placed on 
top of the rock surface (Figure 1). The rock anchor is a titan threaded hollow bar, 73 / 53mm diameter (Ischebeck Titan, 2016).

The tested foundation was installed at different locations in the outcropping schist bedrock (unconfined compressive strength, UCS = $39 \mathrm{MPa}$, rock-quality designation, RQD = $40-50 \%$ ) of a quarry in Ballykinler, Northern Ireland. The adopted installation followed manufacturer's recommendations (Ischebeck Titan, 2016): the anchor was installed in the rock mass with a sacrificial drill bit, using a rotary percussive drilling technique and a weak cement grout as flushing medium, pumped through the hollow center of the anchor. A maximum boring depth of approximately $6 \mathrm{~m}$ was reached. Towards the end of the drilling phase, a 0.4 water / cement ratio grout was injected, as recommended by the anchor manufacturer (Ischebeck Titan, 2016). This grout displaced the weaker flushing medium and, when cured, it formed a bond around the lower portion of the anchor and the rock mass. A free anchor length of $4 \mathrm{~m}$ was achieved by de-bonding the upper section of the anchor bar, this included the section of the anchor within the foundation. Once the anchor was installed, its upper portion, emerging from the rock mass for $2 \mathrm{~m}$, was encapsulated in the foundation footing (Figure 2a). The footing was constituted by two circular steel elements (Figure 2a), bolted on top of each other. The lower element, the one in contact with the rock, is comprised of a steel tubular section, $300 \mathrm{~mm}$ long (in dark blue in Figure 2a), with an inner and outer diameter of 880 and $920 \mathrm{~mm}$, respectively. The lower edge of the tubular pipe was shaped in two alternative configurations: in one case, the edge was beveled with a bevel angle $(\beta)$ of $45^{\circ}$; alternatively, the profile of the edge was flat $\left(\beta=90^{\circ}\right)$. It should be noted that the anchor, although sheathed in the foundation footing, was not coupled with it, i.e. the anchor was not in direct contact with any of the elements of the shear foot. The system is described in detail by Callan et al. (2012). 


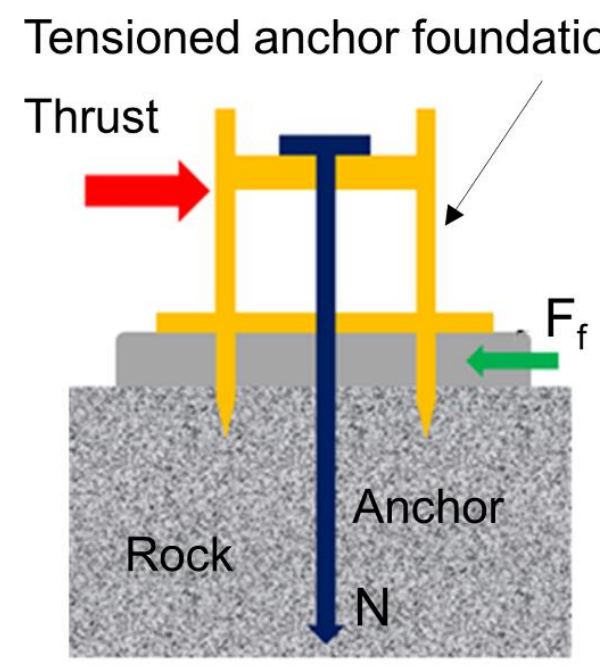

Figure 1 - Sketch of tension anchor foundation system. When the anchor is tensioned, a vertical force $\mathrm{N}$ (composed of tension in the anchor and self-weight) is applied to the structure to be secured. Consequently a friction force $\mathrm{F}_{\mathrm{f}}$ is mobilized, which enables the structure to resist horizontal thrusts.

The foundation footing was in turn housed into a bespoke designed and assembled shear testing rig (Figures $2 b, 2 c$ ), whose function was to transfer the externally applied loads to the footing. The test rig was an elongated fabricated steel frame composed by four $6 \mathrm{~m}$ long 305 UC 97 steel beams, arranged into two layers, the two sides of the rig being connected by means of transversal steel members. Figure $2 \mathrm{c}$ shows an overall design of the testing rig and the foundation footing. When put in place, the rig rested, at one of its extremities, on the foundation footing; the other end was enclosed and supported by a stabilizing frame also composed of steel elements (Figure 3a). This frame was required to prevent any rotational movement of the footing and to ensure that the applied load was a purely horizontal load and not a rotational one. Lubricated steel "knife edge" bearing pads were used to prevent up lift while reducing friction within the system. The stabilizing frame supported the underside of the rig on a slip bearing so that horizontal load was resisted entirely by the interaction of the footing and foundation rock. Figures $3 \mathrm{a}$ and $3 \mathrm{~b}$ show a sketch and a picture of the test rig setup on site. 



Figure 2 - Experimental apparatus, foundation footing and test rig. a and b) exploded view of the elements composing the foundation footing and shear testing rig. c) overall view of test rig and foundation footing, with key dimensions indicated.

After the whole system (foundation and shear testing rig) had been installed, the ground anchor was tensioned by means of four hydraulic jacks, placed on the upper surface of the rig. The applied tension $\left(f_{v}^{+}\right.$in Figure 3a) was progressively increased to the desired level of force, comprised within $490-1470 \mathrm{kN}(50-150 \mathrm{t})$ depending on the different tests (see Section 2.2). A similar system, based on hydraulic jacks, was simultaneously used to apply a vertical force on the rig at the location of the stabilizing frame $\left(f_{v}^{+\prime}\right.$ in Figure $\left.3 \mathrm{a}\right)$, to prevent an excessively asymmetrical loading of the testing rig, hence resisting the overturning moment induced by horizontal loads. In this case, the applied force was set to $441 \mathrm{kN}$ (45 t) in all tests. Once the normal loads had been brought into operation, horizontal shear forces $\left(f_{h}\right.$ in Figure 3a) were applied on the testing rig frame using tensioning bars connecting both ends to anchor blocks. Shear loads were applied either in a single direction, or alternately in 
both directions, depending on the desired loading path. The displacements produced at the base of the foundation footing, in the horizontal and, for some tests, vertical direction, were measured by means of LVDT's.

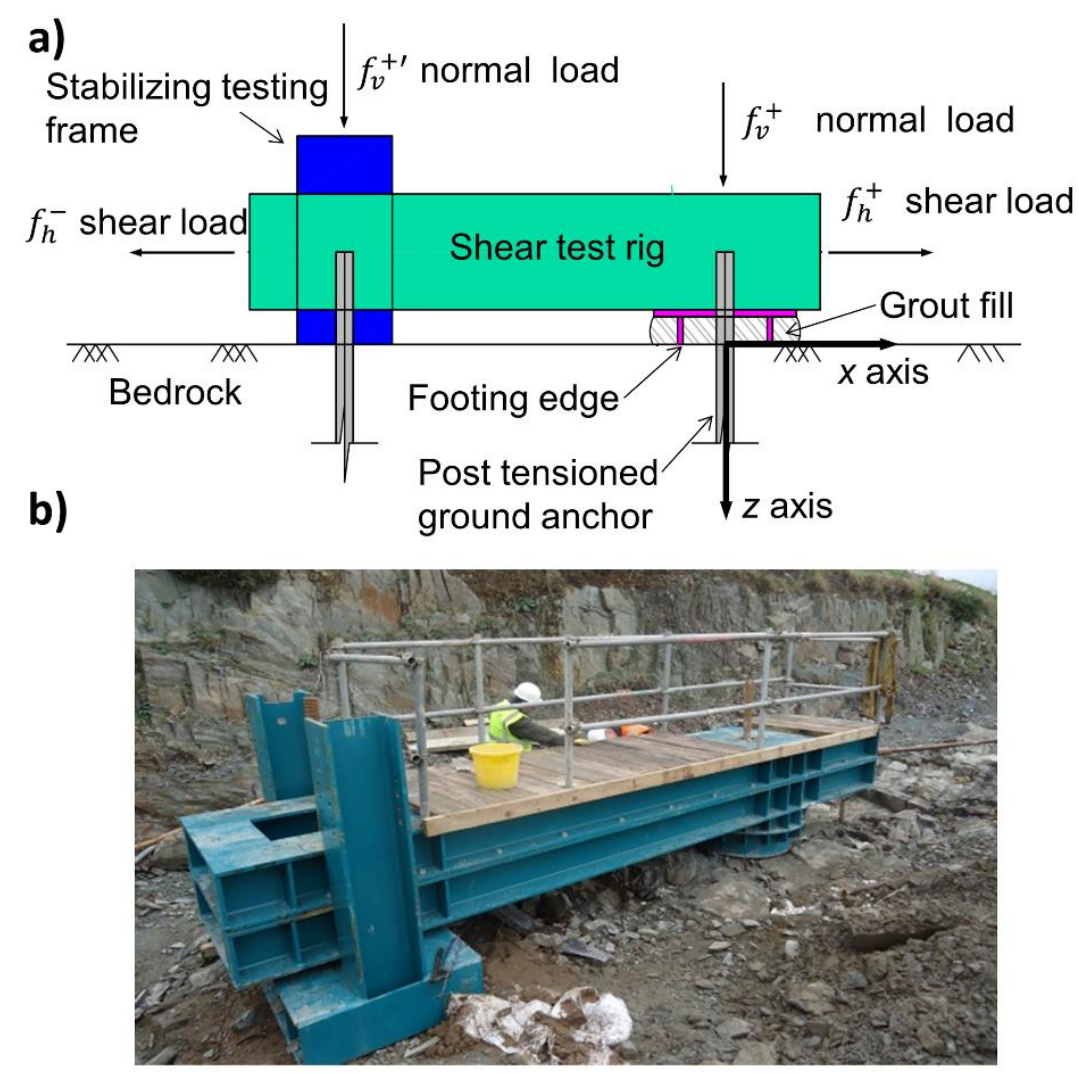

Figure 3 - Experimental apparatus. a) sketch of the shear testing rig when installed on site, representing also the applied loads and the adopted spatial reference system. $\mathrm{f}_{\mathrm{h}}$ and $\mathrm{f}_{\mathrm{v}}$ identify shear and normal forces, respectively. Superscript ${ }^{+}$and $^{-}$indicate the sign (positive or negative) of the applied loads according to the adopted sign convention. b) picture of the test rig system.

\subsection{Experimental testing}

A total of fourteen different tests were conducted using the experimental apparatus described above. Each test, numbered from 1 to 14 , was characterized by a specific installation of the ground anchor, preparation and deployment of the foundation footing and loading path. In experiments including two or more successive loading phases, these are labeled with alphabet 
letters. Table 1 and Table 2 present a summary of the whole experimental work. See Tables A1-A4, in appendix A, for a separate description of all tests. We illustrate here the different experimental conditions adopted for each test.

\subsubsection{Installation of the ground anchor}

As described in Section 2.1, the first step in the execution of the tests was the installation of the ground anchor, which was drilled into the rock mass. Three different experimental setups were investigated:

i) The anchor was drilled into the schist constituting the natural outcropping bedrock at the test site of Ballykinler quarry (Figure 4a). Different locations were chosen in the quarry, so that the foundation was installed on either a relatively competent or a weathered schist. As summarized in Table 2, in tests 1, 6, 7, 8, 9, 10,14 the foundation footing was directly placed on the schist bedrock.

ii) Before drilling the anchor in the bedrock, a cylindrical hole, $\sim 0.4 \mathrm{~m}$ deep and with a diameter of $\sim 1 \mathrm{~m}$, was excavated into the schist rock. The anchor was then driven into the underlying rock volume, which was subsequently backfilled with $40 \mathrm{MPa}$ concrete (standard EN 206-1:2000; European Committee for Standardization, 2000). The concrete was then left to cure for 10 days (period between the installation of the experimental setup and the test execution); it thus formed a compact slab, encased in the bedrock mass and with a smooth upper surface, enclosing the upper segment of the buried portion of the anchor (Figure 4b). This preparation technique was adopted for tests 2, 3, 4, 5 (Table 2). For these tests, the foundation footing was hence placed on the smooth surface of a concrete slab. 
iii) Before drilling the anchor in the bedrock, a trench was excavated in the schist bedrock. A boulder of a different rock type was then housed in the trench and coupled with the surrounding schist mass by adding $40 \mathrm{MPa}$ concrete (standard EN 206-1:2000; European Committee for Standardization, 2000). Here again, the concrete curing time corresponded to the period between the installation of the anchor and the shear test execution (10 days). Finally, the anchor was drilled into this two-layer rock mass, where the lower layer was constituted by the schist bedrock and the upper layer was the encased rockboulder it (Figure 4c). Three different types of rock were used: red sandstone (test 11), Mourne granite (test 12), and gritstone (test 13, Table 2). This preparation technique enabled the foundation performance to be evaluated on better quality, smoother rock materials, when compared to the original schist bedrock of the test site.

\subsubsection{Foundation footing preparation}

The second step in the execution of the tests was the preparation and deployment of the foundation footing (see Section 2.1 and Figures 2a, 2b). Here again, three different alternatives were adopted in the tests:

i) The foundation footing was directly placed on the rock or concrete slab, its lower edge in direct contact with the underlying material. No grout layer (see below) was added between the shear foot and the rock. This configuration was implemented for tests 1, 2, 3 (Naked steel frame in Table 2).

ii) Before the footing was housed in the testing rig, its inner volume was filled with grout and left to cure for 7 days. As a result, the footing face in contact with the underlying rock or concrete slab was a smooth flat surface, with an area $A=$ 
$0.665 \mathrm{~m}^{2}$ (Figure 4d). Tests 4 and 6 were conducted using this footing configuration (Grouted footing in Table 2).

iii) The inner volume of the footing was filled with grout when the footing had been already put in place, and left to cure for approximately 14 days. The grout created a layer adhering to both the steel frame of the footing and the underlying rock or concrete surface (Figure $4 \mathrm{e}, 4 \mathrm{f}$ ). Care was taken to avoid direct contact between the anchor and the grout layer; the anchor bar was protected from contact with the grout using a closed cell foam (polystyrene) insulation to allow movement of the shear foot without generating any shear resistance from the anchor bar. This procedure was followed in tests $5 \mathrm{a}, 7,8,9,10,11,12,13,14$ (Footing grouted in place in Table 2). A partial exception was constituted by tests 5b-d. After reaching sliding failure at the end of experiment 5a (involving the failure of the grout-concrete slab bond, thus producing a rugged contact surface), the subsequent tests $(5 b-d)$ were executed by repositioning the shear foot in its original place (interlocking the grout asperities), without restoring the grout bond. 
a)

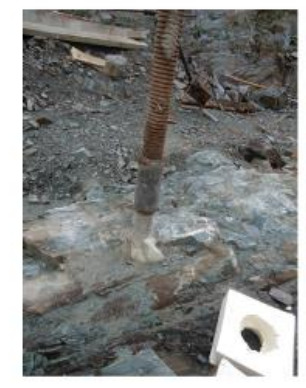

d)

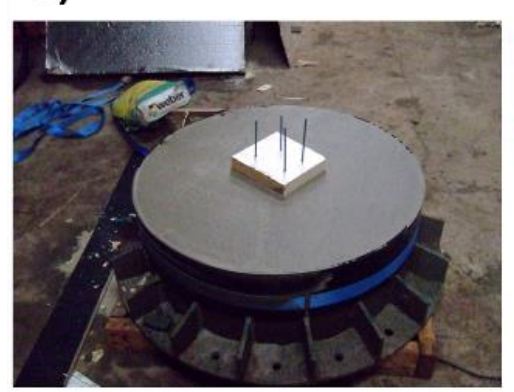

b)

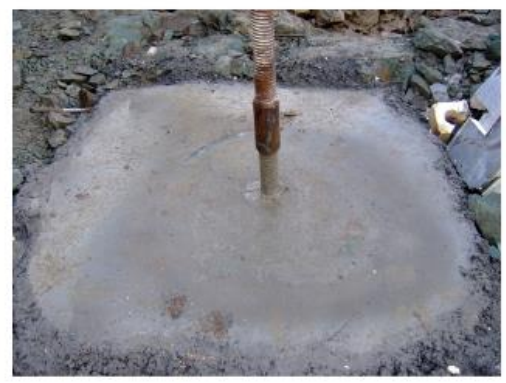

e)

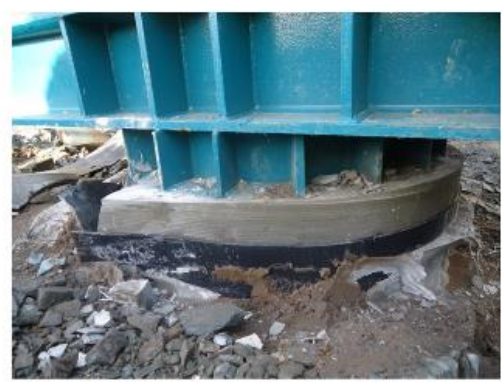

c)

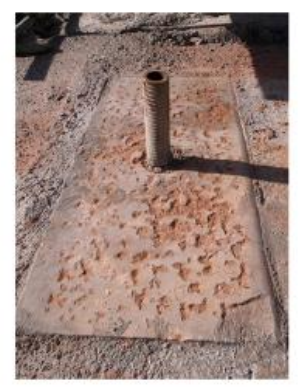

f)



Figure 4-Different alternatives for the installation of ground anchor and the configuration of the foundation footing. Panels a-c: installation of ground anchor. a) ground anchor drilled in schist bedrock. b) anchor surrounded by a concrete slab. c) anchor drilled into a two layer rock formation, the upper layer being constituted by a block of red sandstone (visible in the picture), resting on schist bedrock. Panels $d$-f: configuration of foundation footing. a) footing filled with grout and left to cure before its placement on site. $b$ ) footing and grout layer added when the footing was already in place. c) lower element of the foundation footing and of grout layer cast in place.

\section{$\underline{2.2 .3 \text { Loading path }}$}

After the foundation was completely installed and connected to the testing rig, vertical and horizontal forces were applied as described in section Section 2.1, following the desired loading path. First, a normal force $\left(f_{v}\right)$ was progressively applied on the test rig above the foundation by tensioning the ground anchor with hydraulic jacks (Figure 3a). The normal force was increased up to the desired level $\left(f_{v 0}\right.$, comprised between $490-1470 \mathrm{kN}$, i.e. $50-$ $150 \mathrm{t}$, depending on the different tests), which was then intended to be kept constant in the following phase of shear loading. See Table 1 for a complete list of the values of $f_{v 0}$ adopted 
in all tests. Figures $5 \mathrm{a}$ and $5 \mathrm{~b}$ show a typical increment of vertical force from $0 \mathrm{kN}$ to the desired maximum value of $1471 \mathrm{kN}$, as well as the produced resultant vertical displacements $\left(d_{v}\right)$ measured at the base of the foundation footing (initial phase of test 14a).

Once the preset level of $f_{v}$ has been reached, the following phase of application of shear loads $\left(f_{h}\right)$ was initiated. A variety of different loading-unloading paths, with increasing levels of complexity, was followed in the various tests:

i) Monotonically increasing the horizontal force, applied in a single direction, until the condition of sliding failure at the base of the foundation footing was achieved. The shear force was progressively increased in $98 \mathrm{kN}$ steps, with a 1 minute interval between successive load increments. When failure was considered imminent, the load increments decreased to $49 \mathrm{kN}$ (5 tons) steps. The condition of sliding failure was characterized by a sudden and sharp increase of horizontal displacement measured at the footing $\left(d_{h}\right)$, in response to a stable increase of applied shear load $f_{h}$; the subsequent release of $f_{h}$ showed the predominance of unrecoverable, permanent sets (see Figure 5c showing a typical load-displacement graph from a test involving a monotonic increase of $f_{h}$ to failure, test $5 \mathrm{c}$ ). Overall, tests $1,2,3,4,5,7,8,9 \mathrm{~b}$ implemented this loading path.

ii) Repeated unidirectional loading-unloading cycles. Each cycle involved increasing $f_{h}$ to a maximum value $(490 \mathrm{kN}, 50 \mathrm{t})$, again through $98 \mathrm{kN}$ steps separated by 1 minute intervals. The loading phase was then followed by a reduction to $0 \mathrm{kN}$, completed in a single step. Tests 6 and 9a (Figures 6a, 6b) implement this loading path.

iii) Repeated bidirectional loading-unloading cycles. Each cycle was comprised of alternating load-unload paths in the positive and negative direction (see Figure $3 \mathrm{a}$ for sign reference), reaching the same absolute value for the maximum applied load 
in either direction (see Figures $6 \mathrm{c}, 6 \mathrm{~d}$ for an example from test 14a). Regarding the loading pattern, the horizontal force was progressively raised and decreased, through successive steps $(49-98 \mathrm{kN}$ steps, tests 10-13) or a continuous increase/decrease (test 14, Figures 6c, 6d). The average duration per full cycle was 3.5 minutes for the tests where $\left|f_{h}\right|_{\max }=490 \mathrm{kN}$ (test 14a); 6.1 minutes for the tests with $\left|f_{h}\right|_{\max }=735 \mathrm{kN}$ (tests 10a, 11a, 12a, 13a, 14b); 8.2 minutes for the tests where $\left|f_{h}\right|_{\max }=981 \mathrm{kN}$ (tests $10 \mathrm{~b}, 11 \mathrm{~b}, 12 \mathrm{~b}, 13 \mathrm{~b}$ ) . The final phases of tests 11,13 and 14 , involved cyclic amplitudes $\left|f_{h}\right|>981 \mathrm{kN}$, which resulted in sliding failure.

The different shear loading paths described above (monotonically increasing, unidirectional or bidirectional cycles) were also combined within the same test, in a succession of various loading phases (labelled with letters, see Tables 1,2).
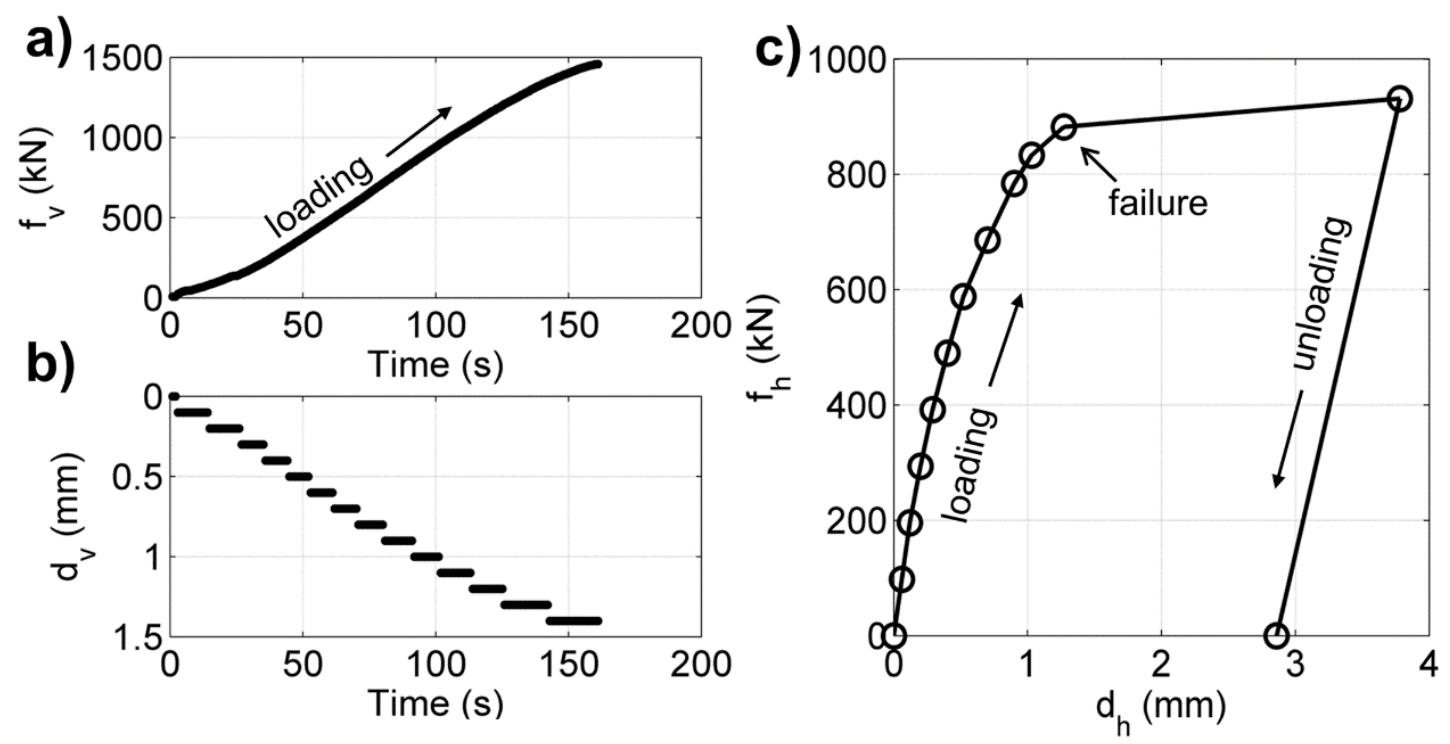

Figure 5 - Application of vertical and horizontal loads and produced displacements. a) and b) typical initial loading phase of performed tests, where the normal force was gradually increased from $0 \mathrm{kN}$ to the desired value of $1471 \mathrm{kN}(a)$. In b) the vertical displacements measured in this phase are shown (a and b refer to test 14a). c) shear load-displacement graph in a typical test (test 5c) involving the unidirectional and monotonic increment of $f_{h}$ until sliding failure is reached. The following unloading path shows the prevalence of permanent sets. 


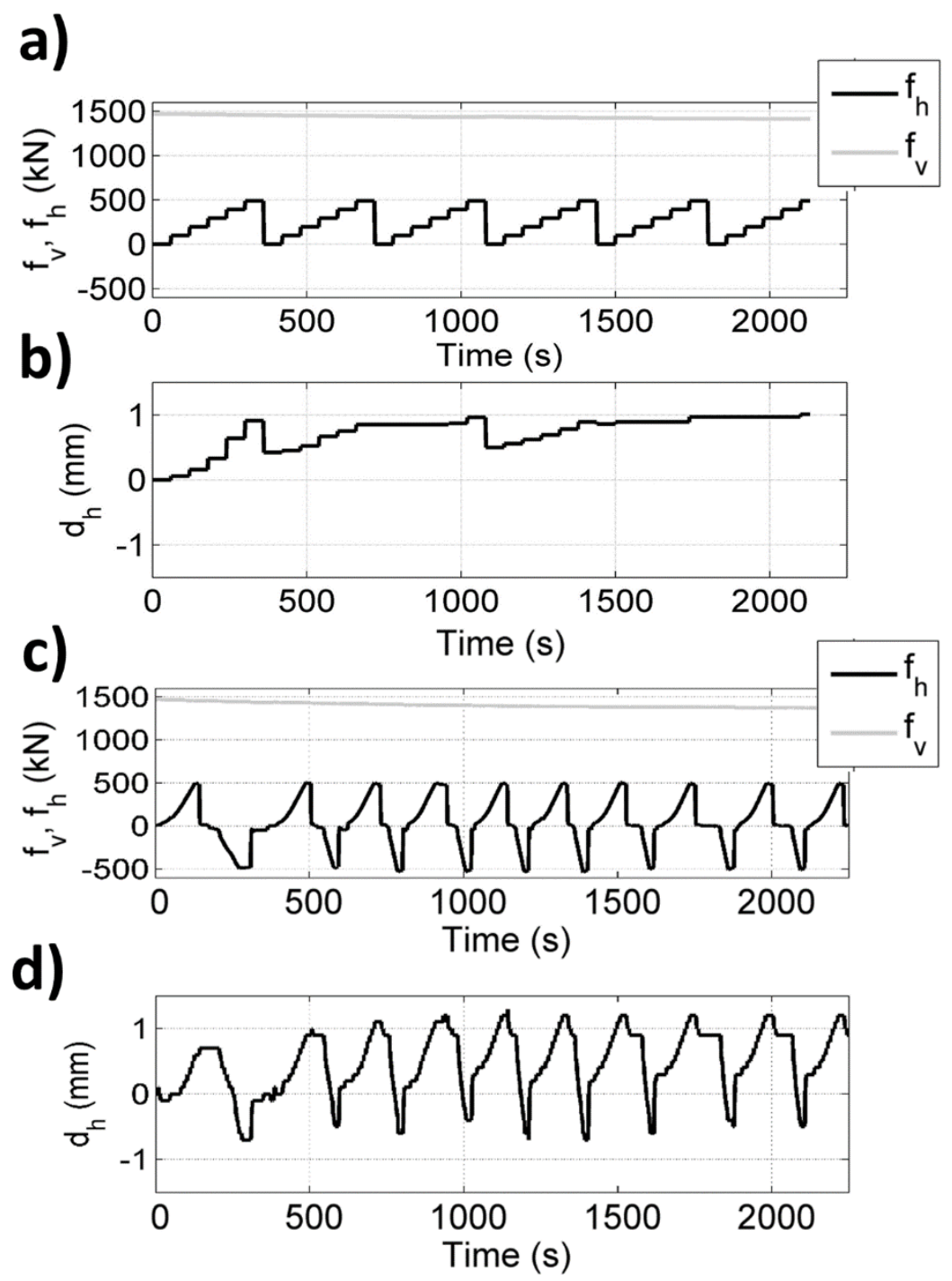

Figure 6 - Unidirectional $(a, b)$ and bidirectional $(c, d)$ cyclic loading paths. a) applied normal and horizontal loads in a typical unidirectional cyclic loading test (test 9a). b) measured horizontal displacements. c) applied normal and horizontal loads in a typical bidirectional cyclic loading experiment (first 10 cycles from test 14a). d) corresponding horizontal displacements.

As shown by Figures 6a and 6c, the phase of application of shear loads is characterized by a gradual, limited decrease in the value of $f_{v}$ (applied normal force ensured by the hydraulic jacks tensioning the anchor). This decrease is due to i) the loss of fluid through jack gaskets (particularly evident in the initial phase of shear loading) and ii) the extension of jack cylinders made possible by the increasing vertical (downward) displacements of the 
foundation footing during the shear loading phase. The loss of pressure in the jacks exerting the normal load $f_{v}$ is limited, amounting to 10 and $12 \%$ in the two most extended tests (test 14a and 14b), involving 48 and 46 cycles of bidirectional shear loading, respectively.

Table 1 and Table 2 present an overall summary of the whole experimental work, describing how the different possible configurations for the foundation footing-rock system and the various loading paths, illustrated above, were combined in a series of tests aimed at evaluating the performance of post tensioned anchor foundations in a variety of different conditions. Each test (numbered from 1 to 14), was characterized by a specific installation procedure leading to a particular configuration for the foundation-rock system; the corresponding loading paths, if constituted by two or more phases, are designated with a letter. See Tables A1-A4, in Appendix A, for a separate description of all tests.

Table 1 -maximum normal load applied before the start of the shear loading phase $\left(f_{v 0}\right)$, expressed in $k N$ and $t$.

\begin{tabular}{|c|c|c|}
\hline \multirow[t]{2}{*}{ Tests } & \multicolumn{2}{|c|}{ Normal load at the start of shear loading phase $\left(f_{v 0}\right)$} \\
\hline & $(\mathrm{kN})$ & (t) \\
\hline $2 \mathrm{a}, 3 \mathrm{a}, 4 \mathrm{a}, 5 \mathrm{a}, 5 \mathrm{~b}$ & 490 & 50 \\
\hline $1 \mathrm{a}$ & 883 & 90 \\
\hline $2 b, 3 b, 4 b, 5 c$ & 981 & 100 \\
\hline $1 \mathrm{~b}$ & 1177 & 120 \\
\hline 8 & 1422 & 145 \\
\hline $\begin{array}{l}1 \mathrm{c}, 2 \mathrm{c}, 3 \mathrm{c} .4 \mathrm{c}, 5 \mathrm{~d}, 6,7,9 \mathrm{a}, 9 \mathrm{~b}, 10 \mathrm{a} \\
10 \mathrm{~b}, 10 \mathrm{c}, 11 \mathrm{a}, 11 \mathrm{~b}, 11 \mathrm{c}, 12 \mathrm{a}, 12 \mathrm{~b} \\
13 \mathrm{a}, 13 \mathrm{~b}, 13 \mathrm{c}, 14 \mathrm{a}, 14 \mathrm{~b}, 14 \mathrm{c}\end{array}$ & 1471 & 150 \\
\hline
\end{tabular}


Table 2 - Table presenting the arrangement of the foundation-rock system and adopted shear loading path. The

bevel angle ( $\beta$ ) of the footing edge is $45^{\circ}$, unless differently specified.

\begin{tabular}{|c|c|c|c|c|c|c|c|c|c|}
\hline & \multicolumn{9}{|c|}{ Material underlying the foundation footing } \\
\hline & \multicolumn{3}{|c|}{ Concrete slab } & \multicolumn{3}{|c|}{ Schist bedrock } & $\begin{array}{c}\text { Sandstone } \\
\text { slab }\end{array}$ & $\begin{array}{c}\text { Granite } \\
\text { slab }\end{array}$ & $\begin{array}{c}\text { Gritstone } \\
\text { slab }\end{array}$ \\
\hline & \multicolumn{9}{|c|}{ Configuration of foundation footing } \\
\hline $\begin{array}{l}\text { Shear loading } \\
\text { path }\end{array}$ & $\begin{array}{l}\text { Naked steel } \\
\text { frame }\end{array}$ & $\begin{array}{c}\text { Grouted } \\
\text { footing }\end{array}$ & \begin{tabular}{|l|} 
Footing \\
grouted \\
in place \\
\end{tabular} & $\begin{array}{c}\text { Naked } \\
\text { steel } \\
\text { frame } \\
\end{array}$ & \begin{tabular}{|c|} 
Grouted \\
footing
\end{tabular} & $\begin{array}{l}\text { Footing } \\
\text { grouted } \\
\text { in place } \\
\end{array}$ & $\begin{array}{c}\text { Footing } \\
\text { grouted in } \\
\text { place }\end{array}$ & $\begin{array}{l}\text { Footing } \\
\text { grouted } \\
\text { in place } \\
\end{array}$ & \begin{tabular}{|l|} 
Footing \\
grouted \\
in place
\end{tabular} \\
\hline $\begin{array}{l}\text { Monotonic, } \\
\text { unidirectional } \\
\text { increment of } f_{h} \text { to } \\
\text { failure }\end{array}$ & $\begin{array}{l}2 \mathrm{a}\left(\beta=90^{\circ}\right), \\
2 \mathrm{~b}\left(\beta=90^{\circ}\right), \\
2 \mathrm{c}\left(\beta=90^{\circ}\right), \\
3 \mathrm{a}, 3 \mathrm{~b}, 3 \mathrm{c}\end{array}$ & $\begin{array}{l}4 a, \quad 4 b, \\
4 c, 5 b, \\
5 c, 5 d\end{array}$ & $5 \mathrm{a}$ & $\begin{array}{l}1 \mathrm{a} \\
\left(\beta=90^{\circ}\right), \\
1 \mathrm{~b} \\
\left(\beta=90^{\circ}\right), \\
1 \mathrm{c} \\
\left(\beta=90^{\circ}\right)\end{array}$ & & $\begin{array}{l}7 \\
\left(\beta=90^{\circ}\right), \\
8, \\
9 \mathrm{~b} \\
\left(\beta=90^{\circ}\right)\end{array}$ & & & \\
\hline $\begin{array}{l}\text { Unidirectional } \\
\text { cycles. Max. } f_{h}= \\
490 \mathrm{kN} \text {. (no. of } \\
\text { cycles) }\end{array}$ & & & & & $6(9)$ & $\begin{array}{l}9 \mathrm{a} \quad(5, \\
\left.\beta=90^{\circ}\right)\end{array}$ & & & \\
\hline $\begin{array}{l}\text { Bidirectional } \\
\text { cycles. Max. }\left|f_{h}\right|= \\
490 \mathrm{kN} \text {. (no. of } \\
\text { cycles) }\end{array}$ & & & & & & $14 \mathrm{a}(48)$ & & & \\
\hline $\begin{array}{l}\text { Bidirectional } \\
\text { cycles. Max. }\left|f_{h}\right|= \\
735 \mathrm{kN} . \text { (no. of } \\
\text { cycles) }\end{array}$ & & & & & & $\begin{array}{l}10 \mathrm{a}(5) \\
14 \mathrm{~b}(46)\end{array}$ & $11 \mathrm{a}(5)$ & $12 \mathrm{a}(5)$ & $13 \mathrm{a}(5)$ \\
\hline $\begin{array}{l}\text { Bidirectional } \\
\text { cycles. Max. }\left|f_{h}\right|= \\
981 \mathrm{kN} . \text { (no. of } \\
\text { cycles) }\end{array}$ & & & & & & $10 \mathrm{~b}(3)$ & 11a (2) & $12 \mathrm{~b}(2)$ & $13 b(2)$ \\
\hline $\begin{array}{l}\text { Bidirectional } \\
\text { cycles to failure. } \\
\text { Max. }\left|f_{h}\right|>981 \\
\text { kN. (no. of } \\
\text { cycles) }\end{array}$ & & & & & & $\begin{array}{l}10 \mathrm{c}(3- \\
\text { no } \\
\text { failure }) \\
14 \mathrm{c}(8)\end{array}$ & $11 \mathrm{c}(4)$ & & $13 \mathrm{c}(4)$ \\
\hline
\end{tabular}

\subsection{Relevant aspects of mechanical behavior of natural rock joints}

This Section introduces relevant aspects of the mechanical behavior of natural rock joints, which have been adopted to assist the interpretation of the shear test data produced in this study.

\subsubsection{Load-displacement relationships}

According to the work of Bandis et al. (1983), the total normal deformation $\left(d_{v t}\right)$ measured in a rock joint subjected to normal stress is constituted by the sum of two components, 
$d_{v t}=d_{v r}+d_{v j}$

where $d_{v r}$ is the portion of vertical displacement due to solid rock compression, and $d_{v j}$ is related to the closure of the rock joint and failure of asperities, and it is referred to as net deformation or closure. Bandis et al. (1983) observed that at the initial loading states, the total observed deformation $\left(d_{v t}\right)$ is predominantly due to the displacements occurring across the joint interface $\left(d_{v j}\right)$. Successively, under increasing values of normal load, the joint closely reaches its closed state, and any further increase in normal stress $\left(\sigma_{n}\right)$ is taken up by the solid rock below and above the joint (therefore $d_{v r}$ becomes dominant). According to Kulhawy (1975) and Bandis et al. (1983), the relationship between $\sigma_{n}$ and $d_{v r}$ may be expressed as a hyperbolic curve with downward concavity, i.e. tending towards a horizontal asymptote on the $\sigma_{n}$ axis:

$\sigma_{n}=\frac{d_{v r}}{\frac{1}{K_{n r i}}+\frac{d_{v r}}{\sigma_{n a}}}$

where $K_{n r i}$ and $\sigma_{n a}$ are the initial tangent of the $\sigma_{n}-d_{v r}$ curve (or initial normal stiffness of solid rock compression) and the horizontal asymptote to the same curve, respectively. To model the behavior of net deformation in rock joints $\left(d v_{j}\right)$, Bandis et al. (1983) suggested the following equation, again a hyperbolic relation, but with an upward oriented concavity (i.e. tending towards a vertical asymptote on the $d_{v j}$ axis):

$$
\sigma_{n}=\frac{d_{v j}}{\frac{1}{K_{n j i}}-\frac{K_{n j i}}{V_{m}} d_{v j}}
$$

where $K_{n j i}$ is the initial normal stiffness for joint closure or failure ( $K_{n j i}$ being the ratio between the increase in applied normal stress and the increase in produced $d_{v j}$ at $\sigma_{n} \rightarrow 0$ ), and $V_{m}$ is the vertical asymptote to the hyperbola and it is the maximum achievable closure for the joint (.i.e. the condition where the joint asperities are perfectly interlocked or have failed).

In a similar fashion, experimental observations of the shear behavior of different types of rock joints and at different levels of normal stresses have led to the definition of hyperbolic 
form for shear load $\left(f_{h}\right)$ - shear displacement $\left(d_{h}\right)$ relationships (Kuhlawy, 1978; Hungr and Coates, 1978; Bandis et al., 1983). In particular, Kuhlawy (1978) has validly proposed and applied:

$$
f_{h}=\frac{d_{h}}{\frac{1}{k_{s i}}+\frac{d_{h}}{f_{h a}}}
$$

where $k_{s i}$ is the initial shear stiffness (the ratio between the increase in applied load and the increase in resultant displacement at $\left.f_{h} \rightarrow 0\right)$ and $f_{h a}$ is the horizontal asymptotic load of the $f_{h}$ - $d_{h}$ hyperbolic curve. These two parameters can be correlated to the quality of the coupling between the two faces of the rock joint. According to Kuhlawy's (1978) and Bandis et al.'s (1983) experimental observations, fresh planar and weathered rock joints are characterized by lower values of $k_{s i}$ and by highly nonlinear $f_{h}-d_{h}$ curves (i.e. by lower values of parameter $f_{h a}$ in equation 4). Vice versa well interlocked, unweathered joints yield steeper and more linear $f_{h}-d_{h}$ relations (features corresponding to higher $k_{s i}$ and $f_{h a}$ ). Kuhlawy (1978) and Bandis et al. (1983) have also investigated the influence of the applied normal stress on shear load displacement relationships, proposing and validating the following equations:

$$
\begin{aligned}
& \frac{k_{s i}}{A}=K_{s i}=K_{j}\left(\sigma_{n}\right)^{n_{j}} \\
& \frac{f_{h a}}{A}=\tau_{a}=\frac{\tau_{\max }}{R_{f}}
\end{aligned}
$$

where $A$ is the rock joint area (so that $K_{\mathrm{si}}=k_{s i} / A$ is the initial slope of the shear stress $\tau-d_{h}$ curve, and $\tau_{a}=f_{h a} / A$ is its horizontal asymptote), $K_{j}=$ stiffness number, $n_{j}=$ stiffness exponent, $\tau_{\max }=$ shear stress at failure, which depends on $\sigma_{n}$ according to the failure envelope (see Section 2.3.2). $R_{f}$, or failure ratio, expresses the ratio of the failure deviator stress to the deviator stress predicted by the hyperbola (Equation 4). $R_{f}$ is $\leq 1$ and it is related to the nonlinearity of the $f_{h}-d_{h}$ curve; values close to 1 indicate a marked curvature of the hyperbola, while lower values correspond to a more linear appearance of the $f_{h}-d_{h}$ relation. 


\subsubsection{Failure criterion}

Several strength criteria, correlating the levels of shear and normal stress at failure, have been defined in the literature for rock masses (Patton, 1966; Jaeger, 1971; Barton, 1973; Hoek and Brown, 1980). Although their mathematical formulation may differ, all criteria envisage a failure envelope that, in a $\tau_{\max }$ (peak shear stress) versus $\sigma_{n}$ (normal stress) representation, is characterized by a steeper slope at low values of $\sigma_{n}$ and by a gentler slope at higher values of $\sigma_{n}$. The two different patterns are determined by the mechanisms controlling the shear resistance of the rock joints. At low values of $\sigma_{n}$, the shear resistance includes a component related to friction and a second component related to dilation. At higher $\sigma_{n}$ the contribution of dilation becomes negligible, and friction and cohesion are the mechanisms controlling the shear resistance (Johnston and Lam, 1989; Roosta et al., 2006).

In agreement with these concepts, the shear strength criterion (Patton 1966) defines a bi-linear envelope, expressed through the following equations:

$$
\begin{array}{ll}
\tau_{\max }=\sigma_{n} \tan \left(\varphi_{b}+\alpha\right) & \text { for low normal stress } \\
\tau_{\max }=c_{0}+\tan \left(\varphi_{b}\right) & \text { for high normal stress }
\end{array}
$$

where $\alpha$ is the asperity angle, $\varphi_{b}$ is the basic friction angle and $c_{0}$ is the cohesion intercept. The angle $\alpha$ is directly related to the dilatant behavior of rock joints under shear loading (Huang et al., 1993; Alejano and Alonso 2005). 


\section{RESULTS AND DISCUSSION}

\subsection{Load-displacement relationships}

\subsubsection{Normal load-normal displacement relationship}

All direct shear tests presented in this work were preceded by the gradual application of the vertical load $\left(f_{v}\right.$; Section 2.2). Figure 7 shows the $\sigma_{n}$ (normal stress) $-d_{v}$ curves recorded for the tests for which measurements of $d_{v}$ are available (tests $10-14$ ). Figures 7a-d, refer to tests where the shear foot was placed on slabs of different rock types (sandstone, granite, gritstone) or on a fresh surface of schist bedrock. The measured $d_{v}$ are modest $\left(\leq 0.6 \mathrm{~mm}\right.$ at $\sigma_{n}$ $\max =2.21 \mathrm{MPa}$ ), and the $\sigma_{n}-d_{v}$ relationships show a similar trend, defined by a curve with downward concavity. Following the consideration of Bandis et al. (1983), that the observed vertical displacements are partly due to solid rock compression and partly to closure or failure of asperities (Equation 1), as the rock surfaces in contact with the shear foot were relatively smooth and flat, it was reasonably assumed that the contribution of asperity closure to the measured deformation was negligible. The observed $d_{v}=d_{v t}$ was, therefore, considered to be purely related to solid rock compression $\left(d_{v r}\right)$; hence these data were fitted with Equation 2 (gray lines in Figure 7). It is worth remarking that the experimental $\sigma_{n}-d_{v r}$ curves observe the same trend defined by Kulhawy's (1975) and Bandis et al.'s (1983) model (Equation 2), that is a hyperbola tending towards a horizontal asymptote. The data fitting is good, expressed here and subsequently with the coefficient of determination, $r^{2}$. The values obtained for the constituent parameters of Equation $2\left(K_{n r i}\right.$ and $\left.\sigma_{n a}\right)$ lie in relatively narrow intervals $(16.75-$ $26.74 \mathrm{MPa} / \mathrm{mm}$ and $2.70-3.74 \mathrm{MPa}$ ), suggesting similar behavior for the different configurations of the foundation footing in solid rock compression.

In Figure 7e, which corresponds to a test where the shear foot was in contact with weathered schist bedrock, the observed $\sigma_{n}-d_{v}$ relationship exhibits a different pattern (curve 
with upward concavity) and larger values of vertical displacement. Considering the state of the rock, in this case the contribution of joint closure $\left(d_{v j}\right)$ could not be neglected, and therefore the measured $d_{v}=d_{v t}=d_{v r}+d_{v j}$ (Equation 1). The $d_{v r}$ component in Figure 7e was reasonably modeled using the hyperbolic curve from Figure $7 \mathrm{~b}$, which refers to a test on fresh schist); gray line in Figure 7b, also reported in Figure 7e). The ratio between $d_{v t}$ and $d_{v r}$ at $\sigma_{n}=1 \mathrm{MPa}$ in Figure 7e is 8, within the range of 5-30 obtained by Bandis et al. (1983). Subtracting $d_{v r}$ from the measured displacement $d_{v t}, d_{v j}$ is obtained (Equation 1, gray circles in Figure 7e), the component related to the closure and/or failure of rock asperities. The obtained $\sigma_{n}-d_{v j}$ graph was interpreted using the corresponding relationship from Bandis et al. (1983; Equation 3), which defines a hyperbolic function with an upward concavity; this is actually the shape of the experimental $\sigma_{n}-d_{v j}$ curve in Figure 7e. The fitting between Equation 3 and the experimental data is excellent $\left(\mathrm{r}^{2}=0.98\right)$, and the resultant $V_{m}$ and $K_{n i}$ parameters are $1.87 \mathrm{~mm}$ and $0.91 \mathrm{MPa} / \mathrm{mm}$, both comparable to values expected for rugged and weathered rock joints according to Bandis et al. (1983). 

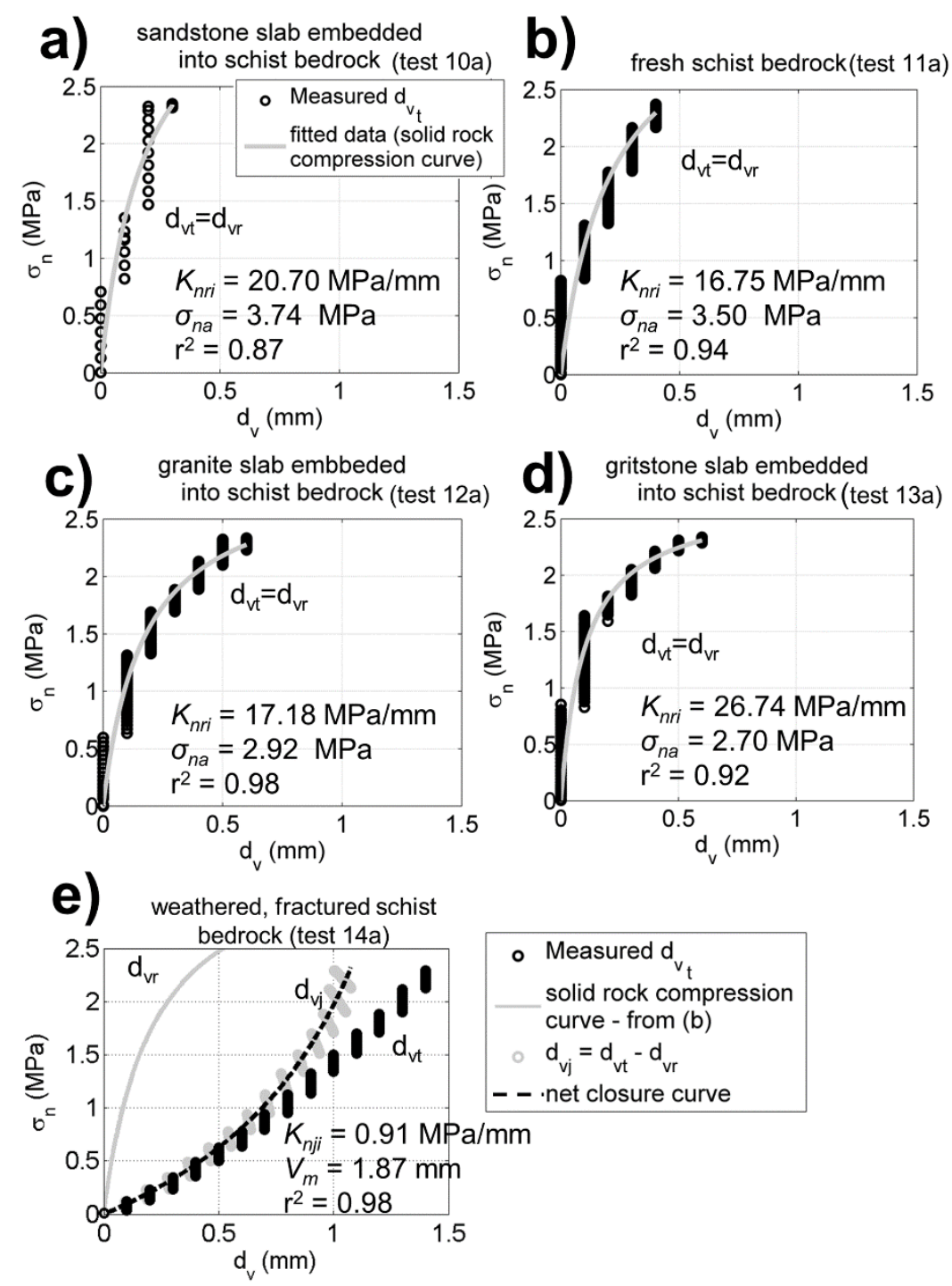

Figure 7 - Experimental $\sigma_{\mathrm{n}}-\mathrm{d}_{\mathrm{v}}$ curves obtained in the initial test phase of gradual application of normal load to the shear foot.

\subsubsection{Shear load-shear displacement relationship}

To investigate the shear load - shear displacement behavior in all tests for which horizontal measurements $d_{h}$ are available (tests 2-6 and 8-14, Appendix A), the pre-peak shear load shear displacement stage was considered from the experiments implementing a monotonic load to failure, or from the first loading path from cyclic tests (Table 2). 



Figure 8 - Experimental $\mathrm{f}_{\mathrm{h}}-\mathrm{d}_{\mathrm{h}}$ curves. a) $\mathrm{f}_{\mathrm{h}}-\mathrm{d}_{\mathrm{h}}$ curve for a test involving the grouted shear foot superimposed to a concrete slab (test $4 c$ ), with $\mathrm{f}_{\mathrm{v} 0}=1471 \mathrm{kN}$. No bond between the shear foot and the concrete surface is present (footing not grouted in place). b) Comparison between $\mathrm{f}_{\mathrm{h}}-\mathrm{d}_{\mathrm{h}}$ curves from two tests involving the grouted shear foot superimposed to a schist bedrock (tests 6 and $9 a$ ), with $\mathrm{f}_{\mathrm{v} 0}=1471 \mathrm{kN}$. In one case the shear foot was grouted in place (hence there is a bond between the foot and the schist bedrock). In the other case no bond is present (footing grouted separately). c) Comparison between pre-peak $\mathrm{f}_{\mathrm{h}}-\mathrm{d}_{\mathrm{h}}$ curves from two tests involving the grouted shear foot superimposed to a concrete slab (tests $4 a$ and $5 a$ ), with $\mathrm{f}_{\mathrm{v0}}=490 \mathrm{kN}$. In one case the shear foot was grouted in place. In the other there is no bond.

As shown in Figure 8, the shear load -shear displacement curves from different tests consistently display non-linear behavior. This feature is in agreement with experimental observations on natural rock joints, for which hyperbolic functions were proposed (Kuhlawy, 1978; Hungr and Coates, 1978; Bandis et al., 1983). The $f_{h}-d_{h}$ function introduced by Kuhlawy (1978; Equation 4) was applied to the experimental load - displacement curves and the best fitting values of $k_{s i}$ (initial shear stiffness) and $f_{h a}$ (horizontal asymptote of the curve) were determined. As shown in Figure 8, the agreement between the hyperbolic function of Equation 4 and the experimental data is excellent. $k_{s i}$ and $f_{h a}$, parameters defining the shape of the $f_{h}-d_{h}$ relationship, can be correlated to the quality of the coupling between the shear foot and the underlying rock or concrete surface. According to Kuhlawy's (1978) and Bandis et al (1983), planar and weathered rock joints are characterized by lower values of $k_{s i}$ and by highly nonlinear $f_{h}-d_{h}$ curves (i.e. by lower values of parameter $f_{h a}$,Equation 5). By contrast, 
well interlocked, unweathered joints yield steeper, more linear $f_{h}-d_{h}$ relationships (i.e. higher $k_{s i}$ and $f_{h a}$ ). Similar behavior can be traced in the load - displacement relationships shown in Figure 8 . Figures $8 \mathrm{~b}, 8 \mathrm{c}$ both compare the $f_{h}-d_{h}$ curves for tests with the same applied normal stress and rock type, but in one case the shear foot was grouted in place, whereas in the other case the grout was left to cure before putting the footing in place. In both cases, the presence of the bond ensured by the grout cured in place resulted in a steeper and more linear $f_{h}-d_{h}$ curve.

Figure 9 displays the initial shear stiffness $\left(k_{s i}\right)$ and horizontal asymptote of the hyperbolic curve $\left(f_{h a}\right)$ derived by fitting Equation 4 to the experimental $f_{h}-d_{h}$ curves from all considered tests. The quantitative characterization of experimental $f_{h}-d_{h}$ curves through the estimation of parameters $k_{s i}$ and $f_{h a}$ is of fundamental importance when evaluating the shear performance of tensioned anchor foundations; steeper $f_{h}-d_{h}$ curves imply smaller displacements at the same level of shear loading (hence less sliding work degrading the foundation footing-rock coupling; Qiu and Plesha, 1991; Donohue and Bergamo, 2016). The following trends in the distributions of the $k_{s i} f_{h a}$ couples can be identified in Figure 9:

i) All factors that contribute to make the shear foot-rock/concrete coupling firmer result in an increase of $k_{s i}$ and/or $f_{h a}$. In particular, a) when only the steel frame of the shear foot is in contact with the underlying concrete slab (red circles in Figure 9), a $45^{\circ}$ beveled edge (tests $\left.3 a, b, c\right)$, penetrating more easily into the concrete surface, yields higher $k_{s i}$ and $f_{h a}$ as compared to a flat edge of the shear foot (tests $2 a, b, c)$; b) an increase of the contact surface between the shear foot and rock/concrete via the filling of the foot steel frame with grout further improves the $f_{h}-d_{h}$ curves (compare circles to dots); c) when the grout is cast in place, i.e. when the grout exerts a bond between the foot and the rock or concrete, a further increase of the $k_{s i}$ and/or $f_{h a}$ is produced (compare circled with plain dots in Figure 
9; see also Figure 8b-c); d) when the shear foot is placed on compact materials (gritstone, sandstone, granite, concrete) it performs better (higher $k_{s i}$ and $f_{h a}$ ) when compared to fractured and weathered rock such as schist bedrock; e) the presence of interlocking asperities on the foot-rock/concrete contact area results in greater $k_{s i}, f_{h a}$ as opposed to smooth surfaces; (compare red dots marked with "smooth" versus "rugged surface" labels).

ii) Given the same shear foot-rock/concrete configuration, $k_{s i}$ and $f_{h a}$ generally increase as the applied vertical load $\left(f_{v 0}\right)$ increases.

Feature (i) is in agreement with Kuhlaway's (1978) and Bandis et al.'s (1983) observations, associating fractured and weathered rock joints to highly nonlinear $f_{h}-d_{h}$ curves, and well interlocked, unweathered joints to steeper and more linear $f_{h}-d_{h}$ relationships.

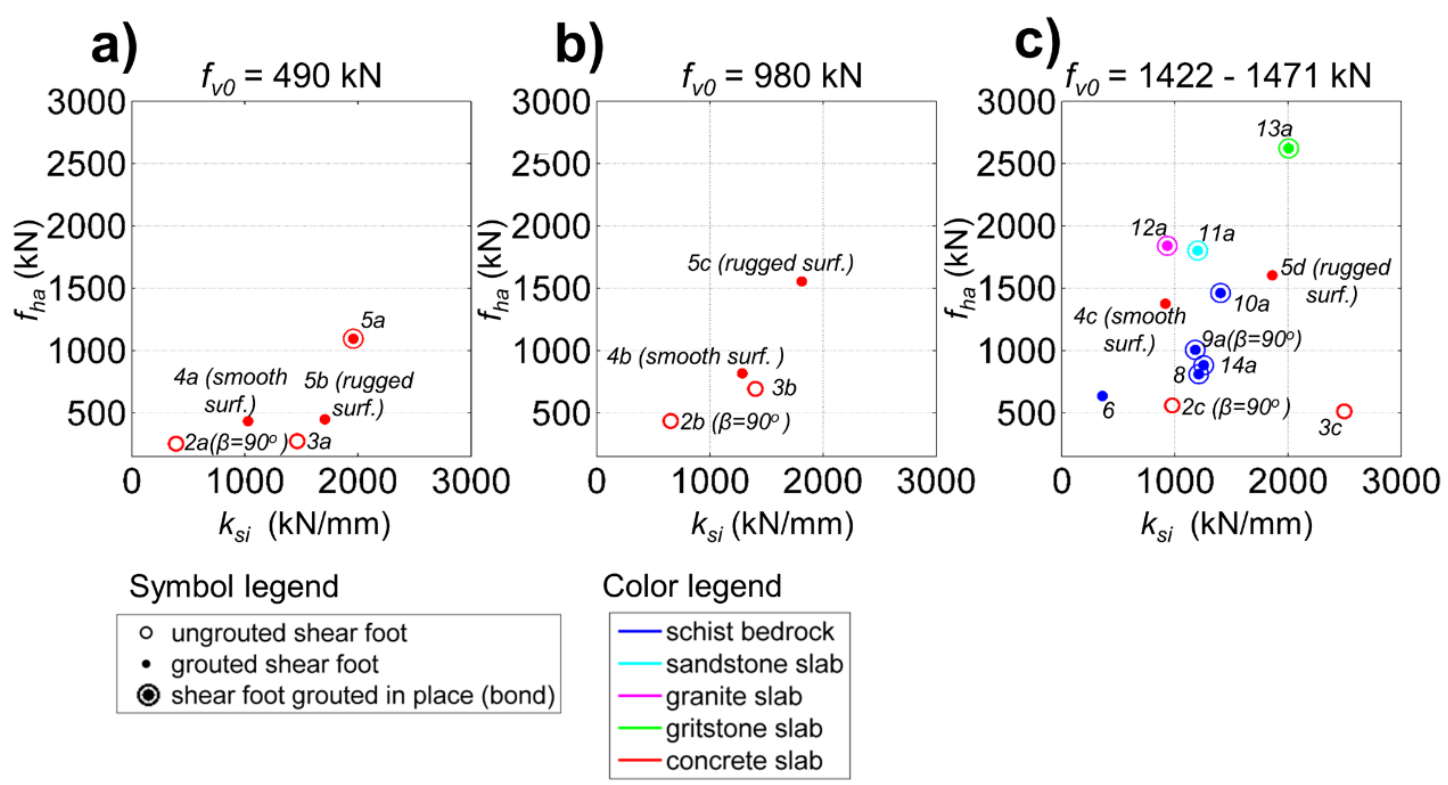

Figure 9 - Parameters $\mathrm{k}_{\mathrm{si}}$ and $\mathrm{f}_{\mathrm{ha}}$ of the hyperbolic relation $\mathrm{f}_{\mathrm{h}}-\mathrm{d}_{\mathrm{h}}$ (Equation 4$)$ obtained from the analyzed shear loading paths (pre-peak shear load - shear displacement stage from the experiments implementing a monotonic load to failure, or from the first loading path from cyclic tests). $\mathrm{k}_{\mathrm{si}}, \mathrm{f}_{\mathrm{ha}}$ couples are subdivided in the three panels according to the value of normal load at the start of the shear loading path $\left(\mathrm{f}_{\mathrm{v} 0}\right)$. Labels refer the 
name of each test. The bevel angle is included in the labels when $\beta=90^{\circ}$ (otherwise $\beta=45^{\circ}$ ). Labels with "smooth" or "rugged surface" allow to appreciate the different performance of tests 4a,b,c versus $5 b, c, d$, otherwise characterized by the same configuration of the footing-concrete system.

As for the dependence of shear load - displacement relationship on the applied normal load (ii, above), this trend is again in accordance with the findings of Kuhlawy's (1978) and Bandis et al. (1983), expressed in Equations 4-- 6. We applied these relationships to the tests where shear loading paths were repeated at different levels of applied normal stress (tests 2 , $3,4,5$ ), to estimate the parameters $K_{j,} n_{j}$ and $R_{f}$ (Equations 5, 6), that describe the relationship between applied shear $\left(\tau=f_{h} / A\right)$, normal stresses $\left(\sigma_{n}=f_{v} / A\right)$ and resultant horizontal displacements $\left(d_{h}\right)$. Here again, the fitting between experimental and simulated $\tau-\sigma_{n}-d_{h}$ curves was good (Figure 10). Obtained $K_{j}, n_{j}$ lie at the lower range of values expected by Kuhlawy (1978) and Bandis et al. (1983) from direct shear tests on rock discontinuities. Consistent with the outcome of the same tests, $R_{f}$ are comprised within $0-1$, with values close to 1 corresponding to highly nonlinear shear stress -displacement curves. Also, in agreement with Kuhlawy's (1978) and Bandis et al.'s (1983) experimental observations, an improvement of the shear foot-concrete coupling (thanks to sharper edges of the foot steel frame in Figure10ab, or thanks to interlocking asperities in Figure 10c-d) results in an increase of $K_{j}, n_{j}$ values and a decrement of $R_{f}$ (i.e. steeper $\tau$ - $d_{h}$ curves).

Overall, the relationships derived from the literature have been successfully applied to the load-displacement relationships observed from a tensioned anchor foundation placed on various types of rock and concrete. These relationships have proven to be adequate in representing (i) the normal load - normal displacement relation during the initial phase of gradual application of vertical load and (ii) the shear load - displacement curve in the subsequent stage of horizontal loading. This enabled changes in the shear load-displacement curves introduced by improvement of the foot-rock/concrete coupling to be quantified. 
Hence, these relationships can be proposed as a tool for the prediction of the response of tensioned anchor foundations under operational loadsas the parameters appearing in the equations (Equations $2-6$ ) are related to the quality and geometry of the contacting materials.

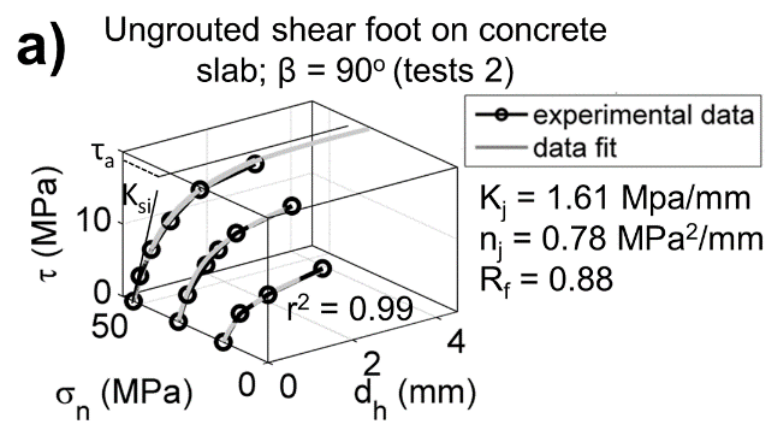

Ungrouted shear foot on
concrete slab; $\beta=45^{\circ}$ (tests 3 )
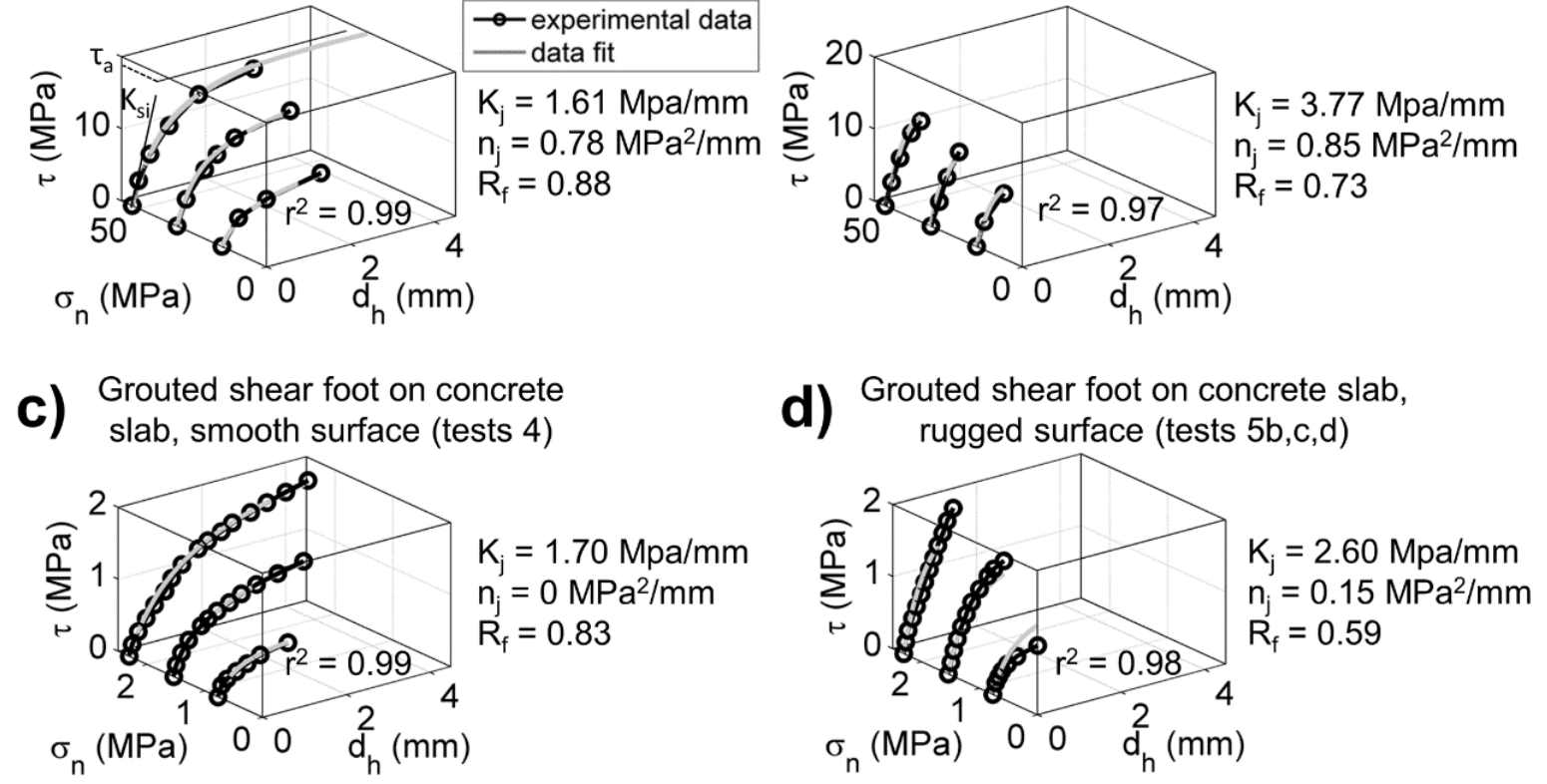

Figure 10 - Shear stress - shear displacement $\left(\tau-\mathrm{d}_{\mathrm{h}}\right)$ curves for different levels of applied normal stress $\sigma_{\mathrm{n}}$. Black circles refer to experimental data; the gray lines correspond to data fitting by applying equations 4, 5 and 6. Close to each panel we report the values of $\mathrm{K}_{\mathrm{j}}, \mathrm{n}_{\mathrm{j}}$ and $\mathrm{R}_{\mathrm{f}}$ (Equations 5 , 6) that best fit the experimental data, as well as the determination coefficients $\mathrm{r}^{2}$. Values of normal and shear stress in panels (a) and (b) differ significantly from corresponding values in (c), (d) because the area of contact shear foot-concrete slab is different, whereas applied loads and observed displacements are similar.

\subsection{Failure criterion}

Figures 11a and 11b display the values of maximum shear load $\left(f_{h \max }\right)$ and vertical load at the sliding failure of the shear footing. The couples of $f_{h, \max }, f_{v}$ show two different trends, one for the tests where a grout layer was added at the base of the foundation footing 
(Figure 11a), and one for the tests where the steel frame of the footing was placed directly on the rock or concrete surface, without grout (Figure 11b). For the first group of tests (Figure 11a), the relationship between applied vertical load and peak shear load appears to be a directly proportional. This behavior suggests the prevalence of frictional and dilatant mechanisms in controlling the shear resistance of the foundation (Johnston and Lam, 1989; Roosta et al., 2006), and it is well approximated by Patton's (1966) formulation of failure criterion for rock joints at low values of normal stress (Equation 7). The slope for this linear failure envelope is 0.95 , corresponding (Equation 7) to a sum of basic friction angle $\varphi_{b}$ and asperity angle $\alpha$ equal to $44.2^{\circ}$, in good agreement with the value $\left(45^{\circ}\right)$ recovered by Hungr and Coates (1978) from direct shear tests on natural rock joints. The fit between Patton's (1966) linear envelope and the experimental data is good, with most of data points being comprised in a $\pm 25 \%$ interval. The only outlier is the failure condition from test 5 a, where the foundation shear foot was grouted in place and superimposed to a concrete slab (circled red dot in Figure 11a). In this case, the bond exerted by the grout on the regular surface of the concrete slab probably gave rise to a cohesive behavior that significantly increased the value of peak shear stress. Despite this, the general compliance to a consistent failure envelope in Figure $11 \mathrm{a}$ is in agreement with the experimental observation that mechanisms involved in the shear resistance of the shear foot-rock system, such as friction in rock-to-rock contact, depend little on lithology (Byerlee, 1978; De Blasio, 2011). Indeed, the performance of the footings grouted in place (circled dots in Figure 11a), was generally better than the tests where the grout layer was added prior to the installation of the shear foot (plain dots in Figure 11a), with the exception of test 8 . The improved behavior offered by such footing configuration can be ascribed to the bond exerted by the cured grout between the foundation footing and the underlying rock surface. The bond strength improves the coupling between the foundation and the rock; consequently, the horizontal force required for shear failure is 
higher than the case where the grout layer is added to the footing before its installation on the rock (in this case, there is no bond, as the grout cures separately from the rock). Even though the results from cyclic tests highlighted a decrease of asperity angle during the iterative shearing process ( Donohue and Bergamo 2016.), hence potentially affecting the value of maximum horizontal load at failure, the number and type of tests reported in Figure 11a were not significant for a reliable comparison between monotonic and cyclic tests. Additionally, previous experimental studies have shown that the value of normal stress or the shearing velocity have a greater impact on the value of shear stress at failure when compared to the influence of loading/unloading cycles preceding failure of the rock joint (Jafari et al., 2003 and 2004).

As for the shear tests conducted by directly placing the ungrouted steel frame of the foundation footing on the rock or concrete surface, the horizontal loads determining sliding failure are significantly lower (compare Figure 11a, 11b). Available data points can be quite well approximated with the Patton (1966) failure criterion at high normal stresses (Equation 8), suggesting both cohesion and frictional mechanisms control the shear resistance. The retrieved value of cohesion ( $209 \mathrm{kN}$, in terms of stresses $c_{0}=7.45 \mathrm{MPa}$ ) is high, comparable to the cohesive strength of an average to good quality rock mass (Hoek, 2001). This can be ascribed to the penetration of the steel frame of the shear foot in the underlying concrete surface (up to $15 \mathrm{~mm}$ when $f_{v} \approx 1471 \mathrm{kN}$ ) for the shear tests conducted on the concrete slab (red circles in Figure 11b). As for the tests performed on schist (blue circles), the high value of $c_{0}$ is likely to be related to interlocking between the hollow steel frame of the shear foot and the rock asperities. This interlocking/penetration mechanism appears to have a limited dependency on the level of vertical stress, as witnessed by the reduced slope of the failure envelope. It is finally worth remarking that most of the values of $f_{h \text { max }}$ from tests where the 
lower edge of the footing was beveled at $45^{\circ}$ (tests $3 a, b, c$ ), lie in the upper portion of this interval, suggesting the greater effectiveness of this configuration (as discussed in 3.1.2).

Figure 11c shows the failure condition in Figure 11a and 11b in terms of shear and normal stresses at the base of the foundation footing $\left(\tau_{\max }\right.$ vs $\left.\sigma_{n}\right)$. The values of normal stress are distributed over two separate intervals (0.74-2.21 and 12.63-52.54 MPa) due to the two different testing configurations of the shear foot. When the section between the steel frame of the shear foot and the rock surface is grouted, the applied vertical loads are distributed over a wide area (approx. $0.665 \mathrm{~m}^{2}$ ) and consequently $\sigma_{n}$ values are comprised in a $0.74-2.21 \mathrm{MPa}$ range. Vice versa, when only the steel frame of the shear foot is in contact with the rock, the same vertical load is distributed over a much smaller area and normal stress values are considerably higher (15-52.54 MPa). Altogether, all data points appear to coherently follow Patton's (1966) failure criterion, which predicts linear behavior with null cohesion intercept at low $\sigma_{n}$, while at higher normal stresses the slope of the linear envelope is lower and a nonzero cohesion is present. 

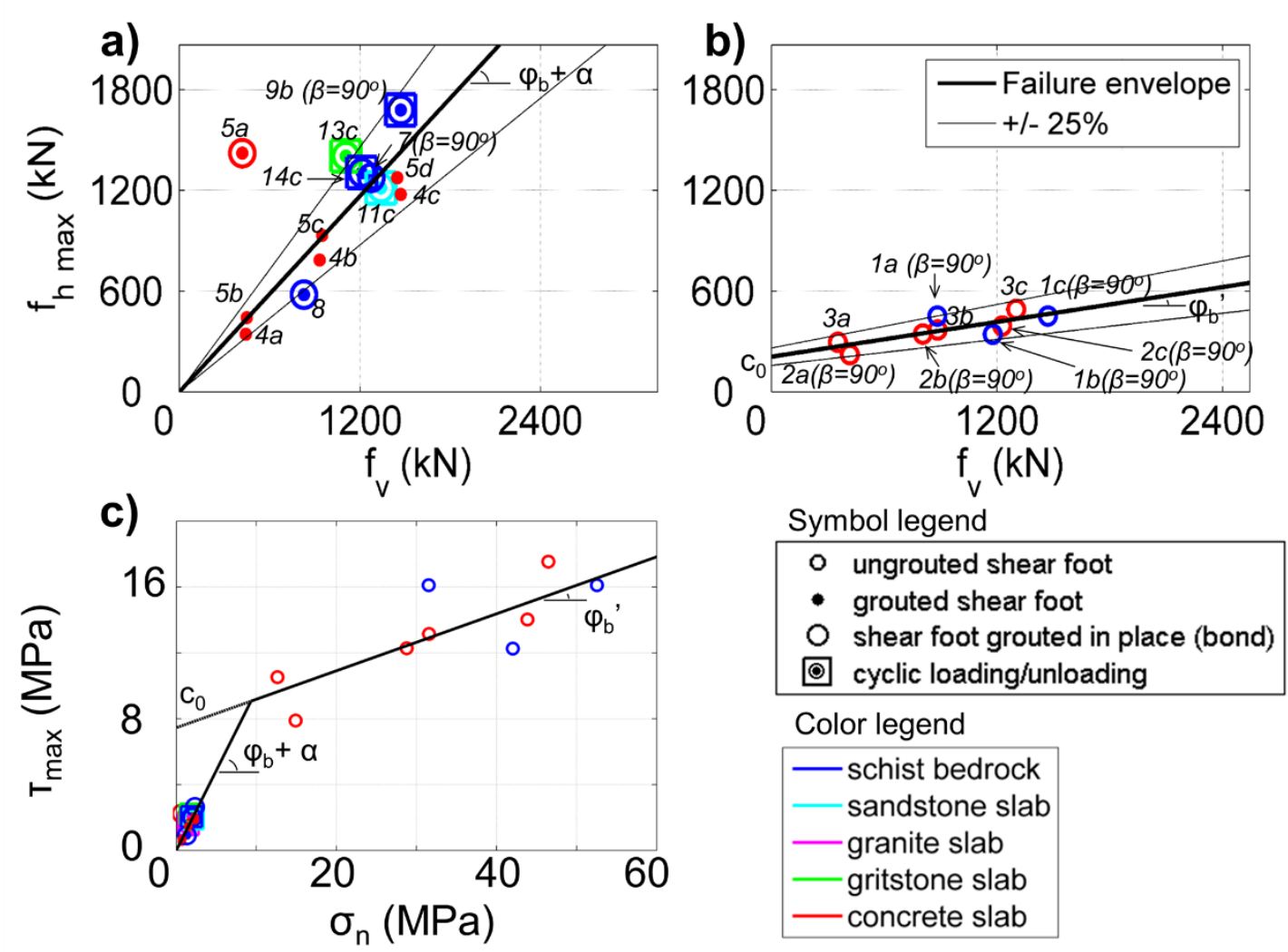

Figure 11 - Maximum shear load and vertical load at the sliding failure of the shear footing. a) maximum shear and normal loads at sliding failure for direct shear tests with a grouted foundation footing. b) maximum shear and normal loads at sliding failure for direct shear tests with an ungrouted foundation footing. Labels in (a) and (b) indicate the name of the test and the bevel angle if $\beta=90^{\circ} ; \beta=45^{\circ}$ otherwise. c) conditions at failure from (a) and (b) expressed in terms of maximum shear and normal stresses.

\section{CONCLUSIONS}

A series of direct shear tests were carried out at full scale with the purpose of evaluating the potential of a tensioned anchor foundation system (designed to fasten tidal turbine devices to a rock seabed) to resist substantial shear loading. In both the testing and subsequent analysis stages, we concentrated on the primary shear resistance mechanism of tensioned anchors. The resistance to horizontal displacement offered by the anchor itself, a mechanism that arises when the foundation footing - rock coupling has already failed, was not analyzed. An ad-hoc experimental apparatus, comprising the tensioned anchor foundation enclosed in a testing rig 
for the application of vertical and horizontal loads, was designed and installed at a test site located in a schist quarry. The tests performed comprised a variety of different configurations for the foundation-rock system, different types of rock (from weathered schist to compact rock or concrete slabs), and various loading paths. The horizontal and vertical loaddisplacement datasets were studied with particular reference to i) the definition of a coherent load-displacement behavior, and ii) the definition of a failure criterion for the condition of sliding failure. For both topics of study, relationships available in the literature that were developed for the analysis of the mechanical behavior of natural rock discontinuities were used and generally showed a good agreement with our experimental data, thus validating their use for the modeling of the performance of tensioned anchor foundations. In particular, i) the shear and normal load - displacement relations can be effectively modeled with hyperbolic relations, whose mathematical parameters correlate with the arrangement of the footing-rock system and with the quality of the rock on which the foundation is installed; ii) the identified failure envelope shows either a cohesive and frictional behavior or a frictional and dilatant behavior, depending on the configuration of the base of the footing.

The key elements that improve the shear resistance of the foundation were also identified as: i) when the ungrouted steel frame of the footing is placed on the rock, a greater shear resistance is obtained by shaping the lower edge of the shear foot with a $45^{\circ}$ angle; ii) adding a layer grout below the foundation footing significantly increases the shear performance of the foundation; iii) adding this grout layer when the footing is already in place further improves the shear resistance of the foundation. The peak shear loads at sliding failure for monotonic and cyclic tests appeared to be relatively similar; however, due to the lack of a significant number of experiments systematically comparing monotonic and cyclic loading paths before failure, it is not possible to draw any reliable conclusions on this topic. Additional tests and studies regarding this subject are needed and envisaged for the future. 


\section{ACKNOWLEDGEMENTS}

The work presented in this paper was part of the "Tension Piles for Marine Renewables" project funded by the Centre for Advanced Sustainable Energy (CASE), Invest Northern Ireland.

\section{REFERENCES}

Abhinav, K.A., and Saha N., 2015. Coupled hydrodynamic and geotechnical analysis of jacket offshore wind turbine. Soil Dynamics and Earthquake Engineering. 73, 66-79.

Adhikari, S., and Bhattacharya S., 2011. Vibrations of wind turbines considering soil structure interaction. Wind and Structures. 15, no. 2, 85-112.

Alejano L.R., and Alonso E., 2005. Considerations of the dilatancy angle in rocks and rock masses. International Journal of Rock Mechanics and Mining Sciences. 42, 481 - 507.

Bandis, S.C., 1980. Experimental studies of scale effects on shear strength and deformation of rock joints. Ph.D. thesis, University of Leeds.

Bandis, S.C., Lumsden, A.C., and N. R. Barton, 1983. Fundamentals of Rock Joint Deformation. International Journal of Rock Mechanics, Mining Sciences and Geomechanics Abstract. 20, no. 6, 249268.

Barton, N., 1973. Review of a new shear strength criterion for rock joints. Quarterly Journal of Engineering Geology. 7, 287-332.

Barton, N. R., and Choubey V., 1977. The shear strength of rock joints in theory and practice. Rock Mechanics. 10, no. 1-2, 1-54

Beer, A. J., Stead D., and Coggan, J. S., 2002. Estimation of Joint Roughness coefficient (JRC) by visual comparison. Rock Mechanics and Rock Engineering. 35, no. 1, 65 - 74.

Bhattacharya, S., Cox J.A., Lombardi D., and Wood D.M., 2012. Dynamics of offshore wind turbines supported on two foundations. Geotechnical Engineering. 166, GE2, 159-169. 
de Blasio, F.V., 2011. Introduction to the Physics of Landslide. Springer Publishing, New York.

Byerlee, J., 1978. Friction of Rocks. Pure and Applied Geophysics.116, no. 4, 615-626.

Byrne, B. W., and Houlsby, 2003. Foundations for offshore wind turbines. Phil. Trans. R. Soc. Lond. A. 361, 2909-2930.

BS EN 14199, 2015. Execution of special geotechnical works - Micropiles. BSI, London.

BS EN 14490, 2010. Execution of special geotechnical works - Soil nailing. BSI, London.

Callan, D., McCarey J., Holland A., 2012. A system and method for the installation of underwater foundations. Patent no. WO/2012/123431.

DETINI, Department of Enterprise, Trade and Investment of Northern Ireland, 2009. Offshore renewable energy strategic action plan 2012-2020, Department of Enterprise, Trade and Investment, Belfast.

Donohue, S., and Bergamo, P., 2016. Assessing the full-scale performance of tension pile foundations under monotonic and cyclic shearing using direct shear tests. Proceedings of the $2^{\text {nd }}$ International Conference on Offshore Renewable Energy (CORE 2016), ASRANet, Glasgow UK.

EMEC, the European Marine Energy Centre Ltd, 2016. http://www.emec.org.uk/ accessed $15 / 1 / 2016$

Eurocode 7, BS EN 1997, 1997. Eurocode 7: Geotechnical design. BSI, London.

European Committee for Standardization, 2000. EN 206-1 Concrete - Part 1: Specification, performance, production and conformity. CEN, Brussels

Gu, X. F., and Haberfield C.M., 2004. Laboratory Investigation of Shaft Resistance for Piles Socketed in Basalt. International Journal of Rock Mechanics and Mining Sciences. 41, no. 3,465 . 
Hoek, E, 2001. Rock mass properties in underground mines. In Hustrulid W. A. and Bullock R. L. (Eds.), Underground Mining Methods: Engineering Fundamentals and International Case Studies. Society for Mining, Metallurgy, and Exploration (SME), Litleton, Colorado. Hoek, E, and Brown E.T., 1980. Empirical Strength Criterion for Rock Masses. Journal of the Geotechnical Engineering Division. 106, GT9, 1013-1035.

Huang, X., Haimson B.C., Plesha M.E., and Qiu X., 1993. An Investigation of the Mechanics of Rock Joints - Part I Laboratory Investigation. International Journal of Rock Mechanics, Mining Sciences and Geomechanics Abstracts. 30., no.3, 257-269.

Hungr. O., and Coates D.F., 1978. Deformability of joints and its relation to rock foundation settlements. Canadian Geotechnical Journal. 15, 239 - 249

IEA - RETD, International Energy Authority Renewable Energy Technology Deployment, 2012. Offshore renewable energy, Routledge, London.

Ischebeck Titan, 2016. http://www.ischebecknz.co.nz/pdf/Injection\%20Piles.pdf. Accessed 19/1/2016.

Jaeger, J.C., 1971. Friction of rocks and stability of rock slopes. Geotechnique. 21, no. 2, 97134.

Jaeger, J. C., Cook N.G.W., and Zimmerman R., 2007. Fundamentals of Rock Mechanics. Wiley-Blackwell, Hoboken, New Jersey.

Jafari, M.K., Hosseini K.A. ,Peller F., Boulon M., and Buzzi O., 2003. Evaluation of the shear strength of rock joints subjected to cyclic loading. Soil Dynamics and Earthquake Engineering. 23, $619-630$.

Jafari, M.K., Pellet F., Boulon M., and Amini Hosseini K., 2004. Experimental Study of Mechanical Behaviour of Rock Joints Under Cyclic Loading. Rock Mechanics and Rock Engineering. 37, no. 1, 3-23. 
de Jesus Henriques, T.A., Tedds S.C., Botsari A., Najafian G., Hedges, T.S., Sutcliffe C.J., Owen I., and Poole R.J., 2014. The effects of wave-current interaction on the performance of a model horizontal axis turbine. International Journal of Marine Energy. 8, 17-35.

Jeffcoate, P., Starzmann R., Elsaesser B., Scholl S., and Bischoff S., 2015. Field measurements of a full scale tidal turbine. International Journal of Marine Energy. 12, 320.

Johnston, I. W., and Lam, 1989. Shear Behaviour of Regular Triangular Concrete/Rock Joints - Analysis. Journal of Geotechnical Engineering. 115, no. 5, 711-727.

Kulhawy, F.H., 1975. Stress deformation properties of rock and rock discontinuities. Engineering Geology. 9, $327-350$.

Kulhawy, F.H., 1978. Geomechanical model for rock foundation settlement. Journal of the Geotechnical Engineering Division. 104 (GT2), 211 - 225.

Meggitt, D.J., Jackson, E., Machin, J. and Taylor, R. 2013. Marine micropile anchor systems for marine renewable energy applications. Proceedings of the Oceans conference, SanDiego. 1-7.

McLaughlin and Harvey, 2016. https://www.mclh.co.uk/projects/openhydro-450t-gravitybase-installation-bay-of-fundy-canada/. Accessed 19/1/2016.

Patton, F.D., 1966. Multiple modes of shear failure in rocks. Proceedings of First Congress of International Society of Rock Mechanics. Vol.1, 509-513.

Qiu, X., and Plesha M. E., 1991. A Theory for Dry Wear Based on Energy. Journal of Tribology. 113, $442-451$.

Renewable UK, 2013. Wave and Tidal Energy in the UK. Renewable UK, London.

Roosta, R. M., Sadaghiani M. H., Pak A., and Saleh Y., 2006. Rock joint modelling using visco-plastic multilaminate model at constant normal load condition. Geotechnical and Geological Engineering. 24, 1449 -1468. 
Scot Renewables, 2016. http://www.scotrenewables.com/, accessed 19/1/2016.

Serrano, A., and Olalla C., 2004. Shaft Resistance of a pile embedded in rock. International Journal of Rock Mechanics and Mining Sciences. 41, 21-35.

Serrano, A., and Olalla C., 2006. Shaft Resistance piles in rock: comparison between in situ test data and theory using the Hoek and Brown failure criterion. International Journal of Rock Mechanics and Mining Sciences. 43, 826-830.

Spagnoli, G., Weixler L., and Finkenzeller Stefan, 2013. Drilling Tools for Installation of Offshore Wind Foundations. Sea Technology. 54, no.1, 47 - 49.

Tiwari, P., Chandak, R. \& Yadav, R. K., 2014. Effect of Salt Water on Compressive Stength of Concrete. Journal of Engineering Research and Applications, 4, no.4, 38-42.

UK Government, 2003. Energy White Paper: our energy future - creating a low carbon economy. Department of Trade and Industry (available at http://webarchive.nationalarchives.gov.uk/+/http:/www.berr.gov.uk/files/file10719.pdf)

Whittaker, T., Collier D., Folley M., Henry A., and Crowley M., 2007. The development of Oyster-A shallow water surging energy converter. $7^{\text {th }}$ European Wave and Tidal Energy Conference, Porto, Portugal, 2007. 


\section{APPENDIX A}

Table A1-details of tests 1-3 (footing of foundation constituted by steel frame only)




Table A2 - details of tests 4-5 (grouted footing placed on a concrete slab)

\begin{tabular}{|c|c|c|c|c|c|c|}
\hline $\begin{array}{l}\text { Test } \\
\text { number }\end{array}$ & $\begin{array}{l}\begin{array}{l}\text { Footing } \\
\text { configuration }\end{array} \\
\end{array}$ & material below footing & \begin{tabular}{|l|}
$\begin{array}{l}f_{v} \text { at start of test } \\
\left(f_{v 0}\right)\end{array}$ \\
\end{tabular} & $f_{h}$ load path & Recorded data & Failure \\
\hline Test $4 \mathrm{a}$ & $\begin{array}{l}\text { grouted footing; } \beta \\
=45^{\circ}\end{array}$ & concrete slab & $490 \mathrm{kN}$ & $\begin{array}{ll}\text { monotonic } & \text { load } \\
\text { increment to } & \text { max. } \\
f_{h}=343 \mathrm{kN} & \end{array}$ & $\begin{array}{l}f_{h}, f_{v}, \\
d_{h}\end{array}$ & yes \\
\hline Test 4b & $\begin{array}{l}\text { grouted footing; } \beta \\
=45^{\circ}\end{array}$ & concrete slab & $981 \mathrm{kN}$ & $\begin{array}{ll}\text { monotonic } & \text { load } \\
\text { increment to } & \max . \\
f_{h}=784 \mathrm{kN} & \\
\end{array}$ & $\begin{array}{l}f_{h}, f_{v}, \\
d_{h}\end{array}$ & yes \\
\hline Test $4 \mathrm{c}$ & $\begin{array}{l}\text { grouted footing; } \beta \\
=45^{\circ}\end{array}$ & concrete slab & $1471 \mathrm{kN}$ & $\begin{array}{ll}\text { monotonic } & \text { load } \\
\text { increment to } & \max . \\
f_{h}=1177 \mathrm{kN} & \\
\end{array}$ & $\begin{array}{l}f_{h}, f_{v}, \\
d_{h}\end{array}$ & yes \\
\hline Test 5a & $\begin{array}{l}\text { footing grouted in } \\
\text { place; } \beta=45^{\circ}\end{array}$ & concrete slab & $490 \mathrm{kN}$ & $\begin{array}{ll}\text { monotonic } & \text { load } \\
\text { increment to } & \text { max. } \\
f_{h}=1422 \mathrm{kN} & \end{array}$ & $\begin{array}{l}f_{h}, f_{v}, \\
d_{h}\end{array}$ & yes \\
\hline Test $5 b$ & $\begin{array}{l}\text { grouted footing; } \beta \\
=45^{\circ}\end{array}$ & concrete slab & $490 \mathrm{kN}$ & $\begin{array}{ll}\text { monotonic } & \text { load } \\
\text { increment to } & \text { max. } \\
f_{h}=441 \mathrm{kN} & \\
\end{array}$ & $\begin{array}{l}f_{h}, f_{v}, \\
d_{h}\end{array}$ & yes \\
\hline Test $5 \mathrm{c}$ & $\begin{array}{l}\text { grouted footing; } \beta \\
=45^{\circ}\end{array}$ & concrete slab & $981 \mathrm{kN}$ & $\begin{array}{ll}\text { monotonic } & \text { load } \\
\text { increment to } & \max . \\
f_{h}=932 \mathrm{kN} & \\
\end{array}$ & $\begin{array}{l}f_{h}, f_{v}, \\
d_{h}\end{array}$ & yes \\
\hline Test 5d & $\begin{array}{l}\text { grouted footing; } \beta \\
=45^{\circ}\end{array}$ & concrete slab & $1471 \mathrm{kN}$ & $\begin{array}{ll}\text { monotonic } & \text { load } \\
\text { increment to } & \max . \\
f_{h}=1275 \mathrm{kN} & \\
\end{array}$ & $\begin{array}{l}f_{h}, f_{v}, \\
d_{h}\end{array}$ & yes \\
\hline
\end{tabular}


Table A3 - details of tests 6-10 (grouted footing placed on schist bedrock)

\begin{tabular}{|c|c|c|c|c|c|c|}
\hline $\begin{array}{l}\text { Test } \\
\text { number }\end{array}$ & $\begin{array}{l}\text { Footing } \\
\text { configuration }\end{array}$ & material below footing & $\begin{array}{l}f_{v} \text { at start of test } \\
\left(f_{v 0}\right)\end{array}$ & $f_{h}$ load path & Recorded data & Failure \\
\hline Test 6 & $\begin{array}{l}\text { grouted footing; } \beta \\
=45^{\circ}\end{array}$ & schist bedrock & $1471 \mathrm{kN}$ & $\begin{array}{l}9 \quad \text { unidirectional } \\
\text { cycles max. } f_{h}= \\
490 \mathrm{kN}\end{array}$ & $\begin{array}{l}f_{h}, f_{v}, \\
d_{h}\end{array}$ & no \\
\hline Test 7 & $\begin{array}{l}\text { Footing grouted in } \\
\text { place; } \beta=45^{\circ}\end{array}$ & schist bedrock & $1471 \mathrm{kN}$ & $\begin{array}{ll}\text { monotonic } & \text { load } \\
\text { increment to } & \text { max. } \\
f_{h}=1030 \mathrm{kN} & \\
\end{array}$ & $f_{h}, f_{v}$ & yes \\
\hline Test 8 & $\begin{array}{l}\text { Footing grouted in } \\
\text { place; } \beta=90^{\circ}\end{array}$ & schist bedrock & $1422 \mathrm{kN}$ & $\begin{array}{ll}\text { monotonic } & \text { load } \\
\text { increment to } & \text { max. } \\
f_{h}=1275 \mathrm{kN} & \\
\end{array}$ & $\begin{array}{l}f_{h}, f_{v} \\
d_{h}\end{array}$ & yes \\
\hline Test 9a & $\begin{array}{l}\text { Footing grouted in } \\
\text { place; } \beta=90^{\circ}\end{array}$ & schist bedrock & $1471 \mathrm{kN}$ & $\begin{array}{l}5 \\
\text { cycles maxidirectional } \\
490\end{array}$ & $\begin{array}{l}f_{h}, f_{v} \\
d_{h}\end{array}$ & no \\
\hline Test $9 \mathrm{~b}$ & $\begin{array}{l}\text { Footing grouted in } \\
\text { place; } \beta=90^{\circ}\end{array}$ & schist bedrock & $1471 \mathrm{kN}$ & \begin{tabular}{|ll} 
monotonic & load \\
increment to & max. \\
$f_{h}=1680 \mathrm{kN}$ & \\
\end{tabular} & $\begin{array}{l}f_{h}, f_{v} \\
d_{h}\end{array}$ & yes \\
\hline Test 10a & $\begin{array}{l}\text { Footing grouted in } \\
\text { place; } \beta=45^{\circ}\end{array}$ & schist bedrock & $1471 \mathrm{kN}$ & $\begin{array}{l}5 \quad \text { bidirectional } \\
\text { loading cycles, } \\
\text { max. }\left|f_{h}\right|=735 \mathrm{kN}\end{array}$ & $\begin{array}{l}f_{h}, f_{v} \\
d_{h}, d_{v}\end{array}$ & no \\
\hline Test $10 \mathrm{~b}$ & $\begin{array}{l}\text { Footing grouted in } \\
\text { place; } \beta=45^{\circ}\end{array}$ & schist bedrock & $1471 \mathrm{kN}$ & $\begin{array}{l}3 \text { bidirectional } \\
\text { loading cycles, } \\
\text { max. }\left|f_{h}\right|=981 \mathrm{kN}\end{array}$ & $\begin{array}{l}f_{h}, f_{v} \\
d_{h}, d_{v}\end{array}$ & no \\
\hline Test 10c & $\begin{array}{l}\text { Footing grouted in } \\
\text { place; } \beta=45^{\circ}\end{array}$ & schist bedrock & $1471 \mathrm{kN}$ & $\begin{array}{l}3 \quad \text { bidirectional } \\
\text { loading cycles, } \\
\max .\left|f_{h}\right|=981- \\
1716 \mathrm{kN}\end{array}$ & $\begin{array}{l}f_{h}, f_{v} \\
d_{h}, d_{v}\end{array}$ & no \\
\hline
\end{tabular}


Table A4 - details of tests 11-13 (grouted footing placed various rock materials)

\begin{tabular}{|c|c|c|c|c|c|c|}
\hline $\begin{array}{l}\text { Test } \\
\text { number }\end{array}$ & $\begin{array}{l}\text { Footing } \\
\text { configuration }\end{array}$ & material below footing & $\begin{array}{l}f_{v} \text { at start of test } \\
\left(f_{v 0}\right)\end{array}$ & $f_{h}$ load path & Recorded data & Failure \\
\hline Test 11a & $\begin{array}{l}\text { Footing grouted in } \\
\text { place; } \beta=45^{\circ}\end{array}$ & Sandstone slab & $1471 \mathrm{kN}$ & $\begin{array}{l}5 \text { bidirectional } \\
\text { loading cycles, } \\
\text { max. }\left|f_{h}\right|=735 \mathrm{kN} \\
\end{array}$ & $\begin{array}{l}f_{h}, f_{v} \\
d_{h}, d_{v}\end{array}$ & no \\
\hline Test $11 \mathrm{~b}$ & $\begin{array}{l}\text { Footing grouted in } \\
\text { place; } \beta=45^{\circ}\end{array}$ & Sandstone slab & $1471 \mathrm{kN}$ & $\begin{array}{l}2 \text { bidirectional } \\
\text { loading cycles, } \\
\text { max. }\left|f_{h}\right|=981 \mathrm{kN}\end{array}$ & $\begin{array}{l}f_{h}, f_{v} \\
d_{h}, d_{v}\end{array}$ & no \\
\hline Test $11 \mathrm{c}$ & $\begin{array}{l}\text { Footing grouted in } \\
\text { place; } \beta=45^{\circ}\end{array}$ & Sandstone slab & $1471 \mathrm{kN}$ & $\begin{array}{l}4 \quad \text { bidirectional } \\
\text { loading cycles, } \\
\text { max. }\left|f_{h}\right|=1177- \\
1216 \mathrm{kN}\end{array}$ & $\begin{array}{l}f_{h}, f_{v} \\
d_{h}, d_{v}\end{array}$ & yes \\
\hline Test $12 \mathrm{a}$ & $\begin{array}{l}\text { Footing grouted in } \\
\text { place; } \beta=45^{\circ}\end{array}$ & granite slab & $1471 \mathrm{kN}$ & $\begin{array}{l}5 \text { bidirectional } \\
\text { loading cycles, } \\
\text { max. }\left|f_{h}\right|=735 \mathrm{kN}\end{array}$ & $\begin{array}{l}f_{h}, f_{v} \\
d_{h}, d_{v}\end{array}$ & no \\
\hline Test $12 b$ & $\begin{array}{l}\text { Footing grouted in } \\
\text { place; } \beta=45^{\circ}\end{array}$ & granite slab & $1471 \mathrm{kN}$ & $\begin{array}{l}2 \text { bidirectional } \\
\text { loading cycles, } \\
\text { max. }\left|f_{h}\right|=981 \mathrm{kN}\end{array}$ & $\begin{array}{l}f_{h}, f_{v} \\
d_{h}, d_{v}\end{array}$ & no \\
\hline Test 13a & $\begin{array}{l}\text { Footing grouted in } \\
\text { place; } \beta=45^{\circ}\end{array}$ & gristone slab & $1471 \mathrm{kN}$ & $\begin{array}{l}5 \text { bidirectional } \\
\text { loading cycles, } \\
\text { max. }\left|f_{h}\right|=735 \mathrm{kN}\end{array}$ & $\begin{array}{l}f_{h}, f_{v} \\
d_{h}, d_{v}\end{array}$ & no \\
\hline Test $13 b$ & $\begin{array}{l}\text { Footing grouted in } \\
\text { place; } \beta=45^{\circ}\end{array}$ & gristone slab & $1471 \mathrm{kN}$ & $\begin{array}{l}3 \text { bidirectional } \\
\text { loading cycles, } \\
\text { max. }\left|f_{h}\right|=981 \mathrm{kN}\end{array}$ & $\begin{array}{l}f_{h}, f_{v} \\
d_{h}, d_{v}\end{array}$ & no \\
\hline Test $13 \mathrm{c}$ & $\begin{array}{l}\text { Footing grouted in } \\
\text { place; } \beta=45^{\circ}\end{array}$ & gristone slab & $1471 \mathrm{kN}$ & $\begin{array}{l}4 \quad \text { bidirectional } \\
\text { loading cycles, } \\
\max .\left|f_{h}\right|=1177- \\
1667 \mathrm{kN}\end{array}$ & $\begin{array}{l}f_{h}, f_{v} \\
d_{h}, d_{v}\end{array}$ & yes \\
\hline
\end{tabular}


Table A5 - details of test 14 (long term, cyclic loading tests on schist bedrock)

\begin{tabular}{|c|c|c|c|c|c|c|}
\hline $\begin{array}{l}\text { Test } \\
\text { number }\end{array}$ & $\begin{array}{l}\text { Footing } \\
\text { configuration }\end{array}$ & material below footing & $\begin{array}{l}f_{v} \text { at start of test } \\
\left(f_{v 0}\right)\end{array}$ & $f_{h}$ load path & Recorded data & Failure \\
\hline Test $14 \mathrm{a}$ & $\begin{array}{l}\text { Footing grouted in } \\
\text { place; } \beta=45^{\circ}\end{array}$ & Schist bedrock & $1471 \mathrm{kN}$ & $\begin{array}{l}48 \quad \text { bidirectional } \\
\text { loading cycles, } \\
\text { max. }\left|f_{h}\right|=490 \mathrm{kN}\end{array}$ & $\begin{array}{l}f_{h}, f_{v} \\
d_{h}, d_{v}\end{array}$ & no \\
\hline Test $14 b$ & $\begin{array}{l}\text { Footing grouted in } \\
\text { place; } \beta=45^{\circ}\end{array}$ & Schist bedrock & $1471 \mathrm{kN}$ & $\begin{array}{l}46 \quad \text { bidirectional } \\
\text { loading cycles, | } \\
\text { max. }\left|f_{h}\right|=735 \mathrm{kN}\end{array}$ & $\begin{array}{l}f_{h}, f_{v} \\
d_{h}, d_{v}\end{array}$ & no \\
\hline Test $14 \mathrm{c}$ & $\begin{array}{l}\text { Footing grouted in } \\
\text { place; } \beta=45^{\circ}\end{array}$ & Schist bedrock & $1471 \mathrm{kN}$ & $\begin{array}{l}8 \quad \text { bidirectional } \\
\text { loading cycles, } \\
\text { max. }\left|f_{h}\right|=981- \\
1471 \mathrm{kN}\end{array}$ & $\begin{array}{l}f_{h}, f_{v} \\
d_{h}, d_{v}\end{array}$ & yes \\
\hline
\end{tabular}

